\title{
MEDENI USUL HUKUKUNDA DAVAYA CEVAP VE CEVAP DILEKÇESI VERMEMENIN SONUÇLARI*
}

\author{
Dr. Orhan EROĞLU**
}

ORCID ID: https://orcid.org/0000-0002-8279-9383

Makalenin Geldiği Tarih: 23.01.2018 Kabul Tarihi: 01.03.2018

* Bu makale hakem incelemesinden geçmiştir ve TÜBİTAK-ULAKBİM Veri Tabanında indekslenmektedir.

** Ufuk Üniversitesi-Öğretim Görevlisi. 



\title{
ÖZ
}

Savunma hakkının özü, kişinin tarafsız, bağımsız, hukuk devleti ilkelerine uygun bir mahkemede yargılanma hakkına sahip olmasına dayanmaktadır. Savunma hakkı tanınmayan bir kişinin, yargılamada temel haklarını kullanma imkânına sahip olduğunu söyleyebilmek mümkün değildir. Gerçekten de bir davaya taraf olan herkes, delillerini, iddia ve vakıalarını mahkemeye sunabilmesi için makul ve eşit şartlarda bir firsata sahip olabilmelidir. Hukuk mahkemesinde yapılan yargılamada savunma hakkı, davalıya daha yargılamanın en başında, dava dilekçesine karşı cevap dilekçesi verebilmesi ile tanınmıştır. Ancak bu hakkı kullanıp kullanmamak davalının takdirindedir. Süresi içerisinde cevap dilekçesi vermemiş olan davalı, davacının dava dilekçesinde ileri sürdüğü vakıaların tamamını inkâr etmiş sayılacak ve yargılama da bu yönde şekillenecektir.

Anahtar Kelimeler: Savunma, cevap dilekçesi, inkâr, davalı, delil.

\section{THE PLEA AND RESULTS OF NO SUBMISSION OF THE PLEA IN CIVIL PROCEDURE LAW}

\begin{abstract}
The essence of right of defense is related to fair trial and judicatured in an independent court based upon principles of the state of law. We could not say that, defendant has ability to use his basic legal rights if he has no right of defense. Plaintiff and defendant shall have equal rights and opportunities to submit their evidences and claims to the court. Right of defense in civil court, is enfranchised to defendant by giving the plea to the court at the begining of judging. However, the defendant does not have to respond to the claims. In this case, the defendant denies each allegation and also the defendant may defend himself by denying all allegations.
\end{abstract}

Keywords: Defence, plea, denial, defendant, evidence. 


\section{I- GİRIŞ}

Kişinin, aleyhinde açılan bir davaya karşı cevap verebilmesi, gösterilen tüm delillerden haberdar olması ve görüş bildirebilmesi gerek Avrupa İnsan Hakları Sözleşmesi'nde gerek Anayasa' da gerekse de kanunlarda adil yargılanma hakkı kapsamında gözetilmesi gereken bir ilke olarak belirtilmiştir. Savunma hakkı kapsamında davalıya, aleyhinde açılan davaya karşıı, dava dilekçesinin kendisine tebliğinden itibaren iki hafta içerisinde cevap dilekçesi verme hakkı tanınmıştır. Davalının aleyhinde açılan davaya karşı cevap dilekçesi verebilmesi bir hak olarak tanındığı için, bu hakkın kullanılıp kullanılmaması davalının takdirine bırakılmıştır. Ancak davalının bu hakkı kullanabilmesi sınırsız değildir. 6100 sayılı Hukuk Muhakemeleri Kanunu ile usul hukukumuzda cevap hakkının kullanılmasına ilişkin bazı sınırlar çizilmiş, cevap dilekçesinin verilmemesi bazı sonuçlara bağlanmıştır. HMK m. 128 hükmü gereğince davaya süresi içerisinde cevap verilmemiş ve aynı zamanda savunma hakkının kasten veya ihmali olarak kullanmamış olması halinde davalı, davacının dava dilekçesinde ileri sürdüğü vakıaların tamamını inkâr etmiş sayılacaktır. Bu makalede; cevap dilekçesinin kapsamı, cevap dilekçesi verilmesine ilişkin çizilen hukuki sınılar, cevap dilekçesinin verilmemiş olmasının davalı, davacı ve mahkeme açısından sonuçları içtihatlar ve uygulamadaki tartışmalar değerlendirilmek sureti ile farklı hukuk sistemleri ile mukayeseli olarak irdelenmiştir.

\section{II- SAVUNMA HAKKI VE SAVUNMANIN ŞEKLI}

\section{A- Savunma Hakkı}

Savunma hakkı, Anayasa m. 36' da hak arama hürriyeti başlığı altında düzenlenmiştir. Anayasa m. 36' ya göre; "Herkes, meşru vasıta ve yollardan faydalanmak suretiyle yargı mercileri önünde davacı ve davalı olarak iddia ve savunma ile adil yargılanma hakkına sahiptir.". Savunma hakkı aynı zamanda Avrupa İnsan Hakları Sözleşmesi ${ }^{[1]}$ (AİHS) m. 6/3' de düzenlenmiştir. Düzenlemeye göre; "Bir suç ile itham edilen herkes aşağıdaki asgari haklara sahiptir:

a) Kendisine karşı yöneltilen suçlamanın niteliği ve sebebinden en kısa sürede, anladığı bir dilde ve ayrıntılı olarak haberdar edilmek;

b) Savunmasını hazırlamak için gerekli zaman ve kolaylıklara sahip olmak;

c) Kendisini bizzat savunmak veya seçeceği bir müdafinin yardımından yararlanmak; eğer avukat tutmak için gerekli maddi olanaklardan yoksun

[1] R.G. 19.03.1954 T., S:8662. 
ise ve adaletin yerine gelmesi için gerekli görüldügünde, re’ sen atanacak bir avukatın yardımından ücretsiz olarak yararlanabilmek;

d) İddia tanıklarını sorguya çekmek veya çektirmek, savunma tanıklarının da iddia tanıklarıyla aynı koşullar altında davet edilmelerinin ve dinlenmelerinin sağlanmasını istemek;

e) Mahkemede kullanılan dili anlamadığı veya konuşamadığı takdirde bir tercümanın yardımından ücretsiz olarak yararlanmak".

Avrupa İnsan Hakları Sözleşmesi m. 6' da "medenî hak ve yükümlülükler" ve "ceza hukuku alanı" olarak ikili bir ayrım yapılmıştır. Sözleşme kapsamına giren hukuk davalarında, tarafların davadaki sıfatlarına bakılmaksızın tüm taraflar için AİHS m. 6 uygulanmaktadır ${ }^{[2]}$. Ceza davaları açısından öngörülen güvenceler ise sadece kendisine bir suç yöneltilen şüpheli veya sanık hakkında uygulanmaktadır. Avrupa İnsan Hakları Sözleşmesi' ne istinaden davalıya savunma hakkının tanınması, hukuki dinlenilme hakkıyla ilgilidir. Bu, sözleşmede yer alan silahların eşitliği ilkesinin bir uzantısıdır ${ }^{[3]}$. Davalıya savunma hakkının tanınmaması halinde adil yargılama gerçekleşmiş olmayacaktır ${ }^{[4]}$.

[2] Avrupa İnsan Hakları Mahkemesi 28.06.2001 T. F.T\&İsviçre Hükümeti; “Adil yargılanma kavramı, kural olarak aynı zamanda davanın taraflarının gösterilen deliller veya sunulan mütalaalar hakkında bilgi sahibi olması ve bunlarla ilgili görüş bildirmesi hakkını da içinde barındırır. Burada asıl önemli olan, davacıların adaletin işleyişine olan güvenidir ki, bu da diğer hususların yanı sıra, tarafların dosyadaki tüm belgelerle ilgili görüş bildirme fırsatı bulduklarını bilmelerine bağlıdır." (aihmbasvuru.com-Erişim tarihi: 10.01.2018).

[3] YHGK, 22.01.2016, E. 2015/2-433, K. 2016/63; “Tensip tutanağ 1 ile verilen kesin süreye rağmen tanıklarını bildirmeyen davacı tanıklarının dinlenmesine karar verilmesine karşın davalı tanıklarının bildirilmesi isteminin reddine karar verilmesi silahların eşitliği ilkesine aykırıdır." (e-uyar.com-Erişim tarihi:10.01.2018).

[4] Pekcanıtez, Hakan: Hukuki Dinlenilme Hakkı, Prof. Dr. Seyfullah Edis’ e Armağan, İzmir 2000, (s.753-791), s. 753; Özekes, Muhammet: Medeni Usul Hukukunda Hukuki Dinlenilme Hakkı, Ankara 2003, s. 85; Pekcanıtez, Hakan/Atalay, Oğuz/Özekes, Muhammet: Medeni Usul Hukuku, Ankara 2013, s. 532; Kuru, Baki/Arslan, Ramazan/ Yılmaz, Ejder: Medeni Usul Hukuku Ders Kitabı, Ankara 2014, s. 318; Görgün, L. Şanal: Medeni Usul Hukuku, Ankara 2015, s. 213; Tanriver, Süha: Medeni Usul Hukuku, C:I, Ankara 2016, s. 658; Arslan, Ramazan/Yılmaz, Ejder/Taşpınar-Ayvaz, Sema: Medeni Usul Hukuku, Ankara 2016, s. 330; Pekcanıtez, Hakan/Özekes, Muhammet/Akkan, Mine/Taş-Korkmaz, Hülya: Medeni Usul Hukuku, C:II, İstanbul 2017, s. 1201; Görgün, Şanal/Börü, Levent/Toraman, Barış/Kodakoğlu, Mehmet: Medeni Usul Hukuku, Ankara 2017, s. 321. Alman hukukunda da maruf ve meşhur vakıalar dahil olmak üzere hakim kanaate ulaşmadan önce, kararını etkileyecek her türlü bilgi ve vakıadan tarafları haberdar etmekle mükelleftir. Bu şekilde taraflar kararı etkileyebilecek her türlü iddia veya vakıaya karşı tavır alabilirler. Rosenberg/Schwab/Gottwald: Zivilprozessrecht, 15., Auflage 1983, s. 114; Zeiss, Walter: Zivilprozessrecht, 9., Auflage 1997, s. 176. 
Savunma hakkı aynı zamanda HMK m. 27' de düzenlenmiştir. HMK m. 27 ' ye göre; “(1) Davanın tarafları, müdahiller ve yargılamanın diğer ilgilileri, kendi hakları ile bağlantılı olarak hukuki dinlenilme hakkına sahiptirler. (2) Bu hak; a) Yargılama ile ilgili olarak bilgi sahibi olunmasını, b) Açıklama ve ispat hakkını, c) Mahkemenin, açıklamaları dikkate alarak değerlendirmesini ve kararların somut ve açı olarak gerekçelendirilmesini, içerir.”. Kanunda belirtilen istisnalar dışında hâkim, iki tarafı dinlemeden karar veremez ${ }^{[5]}$. Savunmada bulunmak, davalı açısından yük değil, bir haktır. Savunma hakkını kullanıp kullanmamak ise davalının tercihidir ${ }^{[6]}$.

Savunma hakkı davalıya tanındıktan sonra, davalının savunma hakkını kullanıp kullanmaması kendi isteğine bağlıdır. Davalı, davaya karşı yazılı olarak cevap vermese bile duruşmaları takip edebilir ${ }^{[7]}$. Davalının savunma hakkını kullanmamasının bazı sonuçları vardır. Örneğin, HMK m. 128 hükmü gereğince davalı, davaya cevap dilekçesi vermediği takdirde davacının ileri sürdüğü tüm vakıaları inkâr etmiş kabul edilir. Davalının ön inceleme duruşmasına katılmaması halinde, ön inceleme duruşmasına katılan davacı iddiasını dilediği gibi değiştirebilir veya genişletebilir.

\section{B- Savunma Hakkının Kapsamı ve Savunmanın Şekli}

Davalı, aleyhinde açılmış olan bir davaya karşı, süresi içerisinde cevap verebileceği gibi mazeretli ya da mazeretsiz olarak cevap vermeyebilir. Davalı, kendisine karşı açılan davada; örneğin, davacının dahi dayanmadığı yeni vakıaları ileri sürebilir, davayı kısmen veya tamamen kabul edebilir. Davalı, takas def' inde bulunabileceği gibi, kendi hak veya alacakları için karşı dava da açabilir ${ }^{[8]}$.

[5] Pekcanıtez/Atalay/Özekes, s. 532, 533; Karslı, Abdurrahim: Medeni Muhakeme Hukuku, İstanbul 2014, s. 444; Kuru/Arslan/Yılmaz, s. 318; Görgün, s. 212; Arslan/ Yılmaz/Taşpınar-Ayvaz, s. 330; Tanrıver, s. 658; Kuru, Baki: İstinaf Sistemine Göre Yazılmış Medeni Usul Hukuku, (Kuru İstinaf), Ankara 2016, s. 247; Pekcanıtez/Özekes/ Akkan/Taş-Korkmaz, s. 1200.

[6] Tanriver, s. 658.

[7] Pekcanıtez/Atalay/Özekes, s. 532; Pekcanıtez/Özekes/Akkan/Taş-Korkmaz, s. 1201.

[8] Bilge, Necip: Medeni Yargılama Hukuku, Ankara 1967, s. 401; Selçuk, Ruza Nurettin: Davaya Cevap, Ankara Barosu Dergisi, $1989 / 5$ (s.840-849), s. 845; Pekcanitez/Atalay/ Özekes, s. 533; Karslı, s. 444; Ulukap1, Ömer: Medeni Usul Hukuku, Konya 2015, s. 273; Kuru/Arslan/Yılmaz, s. 319, 320; Arslan/Yılmaz/Taşpınar-Ayvaz, s. 330; Tanrıver, s. 660; Kuru, s. 247; Pekcanıtez/Özekes/Akkan/Taş-Korkmaz, s. 1201, 1202; Aras, Aslı: Cevap Dilekçesi Verilmesinin Hukuki Sonuçları, D.E.Ü. Hukuk Fakültesi, Prof. Dr. Şeref Ertaş’a Armağan, C:19, Özel Sayı, (s.1927-1952), s. 1930; Budak, Ali Cem/ Karaaslan, Varol: Medeni Usul Hukuku, Ankara 2017, s. 172. 


\section{1- Davacının Davasının Kabul Edilmesi}

Davalı, davacının açmış olduğu davayı ve dava dilekçesinde belirttiği talep sonucunu kısmen veya tamamen kabul edebilir ${ }^{[9]}$. Davalının davayı tamamen kabul etmesi halinde dava sona erer. Şarta bağlı olarak dava kabul edilemez. Davalının, davayı kısmen kabul etmesi halinde; davanın kabul edilen kısmı için yargılama sona ererken, kabul edilmeyen kısım için yargılamaya devam ediliir ${ }^{[10]}$.

Davalının, talep sonucunu değil de davacının bazı iddia veya vakıalarını kabul etmesi davayı kabul olmayıp, ikrardır. Davalının, davacının ileri sürdüğü iddia veya vakıaları kabul etmesi davayı sona erdirmez. Sadece kabul edilen iddia

[9] Bilge, s. 312; Postacioğlu, İlhan: Medeni Usul Hukuku Dersleri, İstanbul 1975, s. 479; Alangoya, Yavuz: Medeni Usul Hukukunda Vakıaların ve Delillerin Toplanmasına İlişkin İlkeler, İstanbul 1979, s. 2; Yıldırım, Mehmet Kamil: Medeni Usul Hukukunda Delillerin Değerlendirilmesi, İstanbul 1990, s. 105; Tanrıver, Süha: Mahkeme Huzurunda Yapılan Kabuller, AÜHFD 1995/I-IV, (Tanrıver, Kabul), s. 291; Tanrıver, Süha: İlamlı İcra Takibinin Dayanakları ve İcranın İadesi, Ankara 1996, (Tanrıver, İlamlı), s. 103; Üstündağ, Saim: Medeni Yargilama Hukuku, C:1,2, İstanbul 2000, s. 573; Bozkurt, Argun: İ̧̧ Yargılaması Usul Hukuku, Ankara 1999, s. 395; Kiraz, Taylan Özgür: Medeni Yargılama Hukukunda İkrar, Ankara 2005, s. 147; Ermenek, İbrahim: Medeni Usul Hukukunda Davayı Kabul, Ankara 2009, s. 5; Alangoya, H. Yavuz/Yıldırım, M. Kamil/Deren-Yıldırım, Nevhis: Medeni Usul Hukuku Esasları, İstanbul 2009, s. 427; Karahacıoğlu, Ali Haydar/Parlar, Aynur: Davanın Açılması ve Aşamaları, Ankara 2012, s. 382, 383; Muşul, Timuçin: Medeni Usul Hukuku, Ankara 2012, s. 439; SungurtekinÖzkan, Meral: Türk Medeni Yargılama Hukuku, İzmir 2013, s. 315; Kuru/Arslan/ Yılmaz, s. 530; Pekcanıtez/Atalay/Özekes, s. 824; Gençsan, Ömer Uğur: 6100 Sayılı Hukuk Muhakemeleri Kanunu Yorumu, Ankara 2013, s. 1071; Karsli, s. 374; Görgün, s. 402; Kuru, İstinaf, s. 540; Tanriver, s. 1010; Görgün/Börü//Toraman/Kodakoğlu, s. 619; Budak, Ali Cem: Medeni Usul Hukuku, İstanbul 2017, s. 286; Pekcanitez/ Özekes/Akkan/Taş-Korkmaz, s. 2025; Y.11.HD., 26.04.2017, E. 2016/3266, K. 2017/2483; "Uyuşmazlık, tarafların üzerinde serbestçe tasarruf edebilecekleri nitelikte olup kabul istemde bulunanın talep sonucuna muvafakat etmesidir. Davayı kabul hüküm kesinleşinceye değin yapılabilecek olup karşı tarafın kabulüne bağlı olmadığı gibi yapıldığı anda kesin hükmün sonuçlarını doğurur. Bu durumda davanın kabulüne ilişkin bir hüküm verilmesini teminen yerel mahkeme kararının bozulması gerekir."; Aynı yönde bir başka karar; Y.12.HD., 8.01.2017, E. 2016/212962, K. $2017 / 565$ (www.sinerjimevzuat.gov. tr-Erişim tarihi: 20.03.2018).

[10] Bilge, s. 313; Üstündağ, s. 573; Alangoya/Yıldırım/Eren-Yıldırım, s. 427; Karahacıŏlu/ Parlar, s. 382, 383; Muşul, s. 440; Pekcanıtez/Atalay/Özekes, s. 533; SungurtekinÖzkan, s. 317; Gençsan, s. 1071; Umar, Bilge: Hukuk Muhakemeleri Kanunu Şerhi, Ankara 2014, s. 904; Kuru/Arslan/Yılmaz, s. 319; Görgün, s. 212; Kuru, İstinaf, s. 248, 540; Postacioğlu, İlhan/Altay, Sümer: Medeni Usul Hukuku Dersleri, İstanbul 2015, 822, 823; Arslan/Yılmaz/Taşpınar-Ayvaz, s. 330, 331, 556, 558; Tanriver, s. 659; Pekcanıtez/Özekes/Akkan/Taş-Korkmaz, s. 1202; Budak/Karaaslan, s. 286; Görgün/ Börü/Toraman/Kodakoğlu, s. 321. 
veya vakıa, taraflar arasında ihtilaflı olmaktan çıkar ${ }^{[11]}$. Türk hukukunda ikrarın açık ve tereddüde yer vermeyecek şekilde yapılması esastır. Alman hukukunda ise ZPO m. 138 hükmü gereğince, taraflardan birinin getirdiği ve diğerinin açıkça muhalefet etmediği vakıalar ikrar edilmiş sayılır ve mahkemece hükme esas alınır ${ }^{[12]}$.

Davanın kabulü, dilekçelerin teatisi aşamasında olabileceği gibi, ön inceleme veya tahkikat aşamasında da gerçekleşebilir. Hatta davalı, kanun yolu incelemesi aşamasında da davayı kabul edebiliri ${ }^{[13]}$. Kabul, muhakemenin ilk duruşmasında vuku bulursa, davalı açısından ekonomik sebeplerle daha yararlıdır. Çünkü davalı, davanın açılmasına kendi hâl ve davranışlarıyla sebebiyet vermemiş ve yargılamanın ilk duruşmasında da davacının talep sonucunu kabul etmiş ise HMK m. 312/2 hükmü gereğince yargilama giderlerini ödemeye mahkûm edilmez. Davalı, davayı kaybetmesi halinde ödeyeceği karar ve ilam karcının üçte ikisini ödemeye mahkûm edilir. Davalı ilk oturumda davayı kabul ederse, Harçlar Kanunu m. 22 hükmü gereğince kendisinden karar ve ilâm harcının

[11] Bilge, s. 451; Üstündağ, s. 628; Alangoya/Yıldırım/Deren-Yıldırım, s. 319; Karahacıoğlu/Parlar, s. 383; Gençsan, s. 805; Karslı, s. 529; Kuru/Arslan/Yılmaz, s. 382; Umar, s. 553; Postacioğlu/Altay, s. 595; Görgün, s. 317; Ulukap1, s. 361; Kuru, İstinaf, s. 355; Arslan/Yılmaz/Taşpınar-Ayvaz, s. 389; Tanrıver, s. 749; Pekcanıtez/ Özekes/Akkan/Taş-Korkmaz, s. 1202; Budak/Karaaslan, s. 286; Görgün/Börü/ Toraman/ Kodakoğlu, s. 467.

[12] Rosenberg/Schwab/Gottwald, s. 78; Zeiss, s. 170; Yıldırım, M. Kamil: İlkeler Işı̆̆ı Altında Medeni Yargilama Hukuku, İstanbul 2011, s. 23.

[13] Tanrıver, İlamlı, s. 105; Üstündağ, s. 571; Ermenek, s. 83; Kuru/Arslan/Yılmaz, s. 530; Sungurtekin-Özkan, s. 317; Pekcanıtez/Atalay/Özekes, s. 821; Gençsan, s. 1087; Muşul, s. 441; Görgün, s. 405; Postacioğlu/Altay, s. 815; Kuru, İstinaf, s. 542; Tanriver, s. 1011; Budak/Karaaslan, s. 286; Y.12.H.D., 21.02.2012, E. 2011/16809, K. 2012/4584, "6100 sayılı HMK'nın 308/2 maddesinde "kabul, ancak tarafların üzerinde serbestçe tasarruf edebilecekleri davalarda hüküm doğurur" aynı yasanın 310. Maddesinde "feragat ve kabul hüküm kesinleşinceye kadar her zaman yapılabilir" 311. Maddesinde ise, "feragat ve kabul kesin hüküm gibi hukuki sonuç doğurur düzenlemelerine yer verilmiştir." (Karahacioğlu/Parlar, s. 383); Y.12.HD., 17.06.2013, E. 2013/116184, K. 2013/22491; "Olayda, alacaklı vekilince davanın kabul edildiğine dair dilekçenin ilk kararın kesinleşmesinden önce dosyaya sunulmuş olduğu anlaşıldığından, alacaklı vekilinin davayı kabul ettiklerine dair beyanı doğrultusunda karar verilmek üzere mahkeme kararının bozulması gerekmiştir."; Y.10.HD., 30.11.2017, E. 2017/4346, K. 2017/8494; "Hükmün kesinleşmesinden önceki herhangi bir aşamada davadan feragat edilebilir. Temyiz edilen ve fakat henüz temyiz Dairesince görüşülmeyen bir karar, usûl hukuku çerçevesinde kesinleşmiş olmadığından, bu aşamada davadan feragat mümkündür." (www. sinerjimevzuat.com.tr- Erişim tarihi: 20.03.2018). 
üçte biri alınır ${ }^{[14]}$. Ayrıca karşı taraf vekili lehine hükmedilecek vekâlet ücretini de daha az öder ${ }^{[15]}$.

İngiliz hukuk sisteminde; dava, dava formunun hazırlanması ile başlar. Davacı talep sonucunu dava formu ile açıklayabileceği gibi, dava formundan başka bir dilekçe ile de açıklayabilir. Talep sonucunun ayrı bir dilekçe ile açıklanması halinde; bu dilekçe ya dava formu ile birlikte ya da dava formunun tebliğinden itibaren on dört gün içerisinde davalıya tebliğ edilir. Dava formu davalıya tebliğ edildikten sonra davalı davayı kabul edebilir. Davayı kabul etmesi halinde davalı bir kabul formu hazırlar. Bu kabul formunda davanın tamamen mi yoksa kısmen mi kabul edildiği açıç̧a belirtilir. Davayı kabul halinde; davaya konu bir para alacağı ise; davalı maktu yargılama giderlerine mahkûm edilecektir. Ayrıca davalı bu kabul formu ile birlikte davaciya borcu taksitler halinde ödeme teklifinde de bulunabilir. Kabul formunda davalının kişisel ve mali durumu hakkında sorular yer almaktadır. Davalının borcu taksitler halinde ödeme teklifi ile birlikte bu soruları da detaylı olarak cevaplandırmalıdır. Davalının kabulü, kısmi bir kabul ise mahkeme davanın kabul edilen kısmını karara bağlayacaktır ${ }^{[16]}$. Görüleceği üzere Anglo-Amerikan Hukuk sisteminde, Kita Avrupası hukuk sisteminden farklı olarak davalı, şayet davayı kabul edecek ise davanın başında mahkeme tarafindan kendisine verilen bir formu doldurmak zorundadır. Bu form, davaya karşı savunma yapacağı zaman hazırlayacağı dilekçeden ve formattan farklıdır.

[14] Kuru/Arslan/Yılmaz, s. 532; Gençsan, s. 1093; Pekcanıtez/Atalay/Özekes, s. 826; Muşul, s. 442, 443; Postacıoğlu/Altay, s. 824, 825; Görgün, s. 407; Ulukap1, s. 430; Kuru, İstinaf, s. 546, 547; Tanrıver, s. 1051, 1052; Öner, Erdoğan/Değirmenci, Cenker: Damga Vergisi ve Harçlar Bilgisi, Ankara 2017, s. 107; Pekcanıtez/Özekes/Akkan/Taş-Korkmaz, C:III, s. 2031; Y.H.G.K., 05.03.2014, E. 2013/14-498, K. 2014/205; "Anlaşmazlık; davanın konusuz kalması, feragat, kabul ve sulh nedenleriyle, delillerin toplanmasına ilişkin ara kararı gereğinin yerine getirilmesinden önce giderilirse tarifedeki ücretin yarısına, karar gereğinin yerine getirilmesinden sonra giderilirse tamamına hükmolunur. Bu durumda karar ve ilam harcının 2/3'ünün davalıdan tahsiline karar verilir. Kabul veya sulh ilk celsede gerçekleşirse karar ve ilam harcının 1/3'ünün davalıdan tahsiline karar verilir. (Harçlar k.22)"; Y.14.HD., 15.11.2016, E. 2015/17397, K. 2016/9399; Y.14. HD., 21.01.2014, E. 2013/12818, K. 2014/1040; Y.23.HD., 25.01.2016, E. 2014/8916, K. 2016/319 (sinerjimevzuat.com.tr-Erişim tarihi:11.01.2018).

[15] Bilge, s. 313; Üstündağ, s. 768; Karahacıŏlu/Parlar, s. 395; Muşul, s. 442; Pekcanıtez/ Atalay/Özekes, s. 533; Sungurtekin-Özkan, s. 328; Özgenç, s. 1093; Kuru, İstinaf, s. 546, 547; Postacıoğlu/Altay, s. 825; Görgün, s. 426; Arslan/Yılmaz/Taşpınar-Ayvaz, s. 558; Ulukapı, s. 430; Tanriver, s. 1051, 1052; Pekcanıtez/Özekes/Akkan/Taş, s. 1201; Budak/Karaaslan, s. 292; Görgün/Börü/Toraman/Kodakoğlu, s. 321.

[16] Bu konuda detaylı bilgi için bakınız; Gündüz, Okan: Anglo-Amerikan Hukuku Işığında Medeni Yargılama Hukukunda Dava Yönetimi, Ankara 2009, s. 105, 106. 
Mahkeme, davalıya dava dilekçesini gönderirken ve davaya ilişkin tebligatı yaparken bu formu da gönderecektir ${ }^{[17]}$.

\section{2- Davacının Davasına Karşı Cevap Dilekçesi Verilmesi}

Davalı, HMK m. 127 hükmü gereğince dava dilekçesinin kendisine tebliğinden itibaren iki haftalık süre içerisinde HMK m. 129' a istinaden bir cevap dilekçesi verebilir. Cevap dilekçesine davacı sayısı kadar örnek eklenmelidir. Cevap dilekçesi, davanın açılmış olduğu mahkemeye verilir. Davalının, davanın açıldığı mahkemenin bağlı olduğu yargı çevresinde ikamet etmemesi halinde, cevap dilekçesi vermek için mahkemenin bulunduğu yere gitmesi gerekmemektedir. Cevap dilekçesini, davanın açıldığı mahkemeye gönderilmek üzere başka yargı çevresinde bulunan nöbetçi mahkemeye sunabilir. Cevap dilekçesi aynı tarihte mahkeme hâkimince muhabere defterine kaydedilir ve havalesi yapılır. Kanunda cevap dilekçesinin yanlış mahkemeye verilmesine ilişkin bir düzenleme bulunmamaktadır. Ancak HMK m. 126/1 hükmü emredici mahiyettedir ve kanun koyucu maddeyi düzenlerken cevap dilekçesinin yanlış mahkemeye verilmesine ilişkin bilinçli boşluk bırakmıştır. Bu nedenle cevap dilekçesinin yanlış mahkemeye verilmesi halinde, yapılan yanlışlık cevap dilekçesinin verilmesi süresi içerisinde düzeltilmezse, davalının cevap dilekçesi vermediğinin kabulü gerektiği kanaatindeyim. Cevap dilekçesi, havale edildiği tarihte verilmiş sayılır. Cevap dilekçesinin nöbetçi mahkeme kanalı ile gönderilmesi halinde, nöbetçi mahkemece havale yapılan tarihte cevap dilekçesi verilmiş sayılır. Cevap dilekçesinin verilmesi bir harca tabi değildir. Ancak davalı, cevap dilekçesinin karşı tarafa tebliğ edilmesi için gerekli tebliğ giderlerini ödemelidir ${ }^{[18]}$.

Davalı, dava dilekçesinin kendisine tebliğini müteakip iki haftalık süre içerisinde cevap dilekçesi hazırlayamayacağını düşünüyorsa mahkemeden ek süre talep edebilir. Mahkeme, davalının talebi üzerine yapacağı incelemede durum ve koşullara göre cevap dilekçesinin hazırlanmasının çok zor yahut imkânsız olduğu kanaatine varırsa, davalıya sadece bir defaya mahsus olmak üzere ek süre

[17] Friedenthal, Jack H. / Kane, Mary Kay / Miller, Arthur R.: Civil Procedure, St.Paul 2015, s. 296; Loughlin, Paula/Gerlis, Stephen: Civil Procedure, Londra 2004, s. 145147; Neil, Andrews: English Civil Procedure, Norfolk 2003, s. 493, 494; Fleming, James Jr./Geoffrey, C. Hazard Jr./Leubsdorf, John: Civil Procedure, Newyork 2001, s. 243, 244; Sime, Stuart: Civil Procedure, Newyork 2004, s. 103, 104.

[18] Pekcanıtez/Atalay/Özekes, Medeni Usul Hukuku, s. 551; Umar, tebligat giderlerinin davacının yatırdığı gider avansından karşılanması gerektiği görüşündedir, Umar, Şerh, s. 408. Tebligat Kanunu m. 34/2 uyarınca davalı tebligat giderlerini ödemekle yükümlüdür. Bu nedenle Umar' in görüşüne katılmıyorum. 
verebilir. Doktrinde ağırlıklı görüş, cevaba cevap ve ikinci cevap dilekçesi için ek süre talep edilebileceği yönündedir ${ }^{[19]}$. Ancak, HMK m. 127/1' de davalıya ek süre tanınmasındaki amaç; davalının aleyhinde böyle bir dava açıldığından dava dilekçesinin tebliği ile haberdar olmasıdır ${ }^{[20]}$. Davalının, yeni haberdar olduğu bir dava için iki haftalık süre içerisinde cevap dilekçesi sunamayacak olması kabul edilebilir bir durumdur. Çünkü davalının, aleyhinde açılan davada savunma hakkını tam olarak kullanabilmesi ve etkili bir cevap dilekçesi sunmak için araştırma yapması, kayıtları incelemesi ya da bazı bilgi ve belgelere ulaşması gerekebilir. Bu bilgi ve belgelere ulaşması için başka bir yerden talep etmesi yahut bilgi veya belgeleri başka yerden getirtmesi gerekebilir. Ancak, cevaba cevap ve ikinci dilekçeler açısından böyle bir durum söz konusu değildir. Çünkü davalı, normal şartlarda cevap dilekçesi ile gerekli araştırmaları ve incelemeleri yapmıştır. Normal olmayan bir şart içerisinde ise eski hale getirme kurumu ile ikinci cevap dilekçesi vermesi mümkündür.

İkinci dilekçeler açısından da ek süre istenebileceğine ilişkin görüşte olan yazarların dayanağı HMK m. 136/2' dir. HMK m. 136/2' de yer alan " niteliğine aykırı düşmediği sürece” ibaresinin doğru yorumlanması gerekmektedir. Kanun koyucu burada dava ve cevap dilekçesi ile ilgili hükümlerin kesin olarak değil, niteliğine uygun olduğu sürece cevaba cevap veya ikinci cevap dilekçesi açısından uygulanacağını belirtmektedir. Burada HMK m. 136/2' nin, HMK m. 131 ile birlikte değerlendirilmesi gerekmektedir. Nitekim HMK m. 131' in madde gerekçesine göre; "Davalının, cevap dilekçesi vermekle artık usulî itirazlarını bildirdiğini veya böyle bir itirazı olmadığını ve esasa girdiğini kabul etmek gerekir." . Davalı cevap dilekçesi ile tüm usulî itirazlarını bildirmiştir ve artık ikinci cevap dilekçesi ile artık esasa ilişkin cevaplarını sunacaktır. Bunun için ise ek bir süre öngörülmesi davanın gereksiz yere uzamasına sebebiyet verecektir. Nitekim ek süre hakkı HMK m. 127/1' de davalıya tanınmış bir haktır. Bu hakkın hem cevap dilekçesinde hem de ikinci cevap dilekçesinde davalıya tanınması, davacı açısından orantısız olacaktır. Çünkü, davalı ikinci cevap dilekçesinde davacının cevaplarına cevap verirken; davacı da cevaba cevap dilekçesi ile davalının cevaplarına cevap vermektedir. Bu nedenle cevaba cevap

[19] Karslı, s. 446; Görgün, s. 221; Pekcanıtez/Özekes/Akkan/Taş-Korkmaz, s. 1248; Görgün/Börü/Toraman/Kodakoğlu, s. 332.

[20] Postacıoğlu/Altay, ikinci dilekçeler açısından süre uzatım verilebilmesi için titiz ve kıskanç davranılması, ciddi sebepler bulunması halinde ikinci dilekçeler açısından süre uzatım verilmesi gerektiği, süre uzatım verilecek ise de bu sürenin bir aydan kısa olması gerektiği görüşündedir. (Postacıoğlu/Altay, s. 473). Postacıoğlu/Altay, her ne kadar ikinci dilekçeler açısından süre uzatım verilebileceği görüşünde ise de ek sürenin her durumda değil, istisnai hallerde verileceğini bildirmesi ile bizim görüşümüze yakın görüş bildirmiştir. 
ve ikinci cevap dilekçesinde davacı ve davalının şartları eşit olmalıdır. Ayrıca, kanun koyucu HMK m. 136/2'de verilecek olan ikinci dilekçeler açısından HMK m. 127/2 hükümlerinin uygulanması kastında olsa idi; HMK m. 127/2' de "bir defaya mahsus olmak" ibaresini kullanmazdı. Hakkaniyet gereğince ikinci dilekçeler açısından ek süre talep edilemeyeceği kanaatindeyiz.

Davalı, cevap dilekçesinde birbirinden farklı savunma sebeplerine dayanabilir. Davalının dayanacağı savunma sebepleri usul hukukuna ilişkin olabileceği gibi, maddi hukuka ilişkin de olabilir. Mahkeme öncelikle usul hukukuna ilişkin olan savunma sebeplerini inceler. Şayet usul hukukuna ilişkin savunma sebepleri, yargılamaya devam edilerek davanın karara bağlanmasına engel değilse, mahkeme maddi hukuka ilişkin savunma sebeplerini incelemeye başlar. Ayrıca davalı, usul hukukuna veya maddi hukuka ilişkin savunma sebeplerini ileri sürmeksizin sadece davacının ileri sürdüğü iddia veya vakıaları çürütecek mahiyette cevaplar vererek, davacının davasının reddedilmesini sağlamaya çalışabilir ${ }^{[21]}$. Davalı, sadece savunma yapmakla yetinmeyip ayrıca davacıya karşı mevcut olan bir hakkının hüküm alına alınmasını istiyorsa, talebi ile asıl davada ileri sürülen talep arasında takas veya mahsup ilişkisinin bulunması yahut bu davalar arasında bağlantının mevcut olması şartıyla, cevap dilekçesiyle veya esasa cevap süresi içinde ayrı bir dilekçe vermek suretiyle karşı dava açabilir.

\section{a. Usule İlişki Savunma Sebepleri}

Davalının, davacının davasını kabul etmemesi halinde savunma yapması kaçınılmazdır. Savunma sebeplerinin usule ve esasa ilişkin olması mümkündür. Eğer davalının savunma sebepleri hem usule hem de esasa ilişkin ise; mahkeme öncelikli olarak usule ilişkin savunma sebeplerini göz önünde bulunduracaktır. Usule ilişkin savunma sebeplerinin yerinde olması halinde mahkeme, davanın esasına girmeden davayı usulden reddedecektir ${ }^{[22]}$. Çünkü, usule ilişkin hususlar davanın esastan incelenmesini engellemektedir ve bu durumda mahkeme esastan incelemeye geçemeyecektir. Usule ilişkin savunma sebeplerinin başında dava şartları bulunmaktadır. Dava şartları hem mahkemece kendiliğinden dikkate

[21] Karafakih, İsmail Hakkı: Hukuk Muhakemeleri Usulü Esasları, Ankara 1952, s. 144; Bilge, s. 40; Karslı, s. 444; Ulukapı, s. 273; Görgün, s. 213; Kuru, İstinaf, s. 247; Arslan/Yılmaz/ Taşpınar-Ayvaz, s. 331; Tanrıver, s. 661; Pekcanıtez/Özekes/Akkan/ Taş, s. 1207; Budak/Karaaslan, s. 286, 287; Görgün/Börü /Toraman/ Kodakoğlu, $322,323$.

[22] Bilge, s. 401; Üstündağ, s. 280, 281; Pekcanıtez/Atalay/Özekes, s. 534; Ulukapı, s. 274; Kuru, İstinaf, s. 252; Arslan/Yılmaz/Taşpınar-Ayvaz, s. 331; Pekcanıtez/Özekes/ Akkan/Taş-Korkmaz, s. 1217. 
alınabilecek hem de davalı açısından her aşamada ileri sürülebilecek usule ilişkin bir savunma sebebidir. Açılmış olan bir davada, dava şartlarının tam olmaması halinde esastan inceleme yapılamaz. Davanın esasının incelenerek karara bağlanması, dava şartlarının varlığına ya da yokluğuna bağlıdır. Dava şartlarının mevcut olup olmadığını hâkim kendiliğinden inceler ${ }^{[23]}$. Davalı da dava şartlarının varlığını ya da yokluğunu ileri sürerek hâkime yardımcı olabilir. Dava şartlarının bir kısmı olumlu bir kısmı da olumsuzdur. Olumlu dava şartları, davanın açılması sırasında bulunması gereken şartlardır. Olumsuz dava şartları ise davanın açılması sırasında bulunmaması gereken şartlardır ${ }^{[24]}$.

Usule ilişkin diğer savunma sebepleri ise ilk itirazlardır. İlk itirazlar dava şartlarından farklıdır. Ancak davanın başında ileri sürüldügünde dikkate alınırlar. İlk itirazlar, davanın esasına girilmesini önleyen birer dava engelidir. İlk itirazların neler olduğu HMK m. 116' da sınırlı sayı (numerus clausus) olarak sayılmışıır ${ }^{[25]}$. Bunlar; yetki itirazı, işbölümü itirazı ve tahkim itirazıdır. Yetkinin kesin yetki olmadığı durumlarda, yetki itirazı ancak ilk itiraz olarak ileri

[23] YHGK., 05.02.2003, E. 2003/21-30 - K. 2003/57; “Dava şartları, mahkemenin davanın esası hakkında yargılamada bulunabilmesi için gerekli olan şartlardır. Diğer bir anlatımla; Dava şartları, dava açılabilmesi için değil mahkemenin davanın esasına girebilmesi için aranan Kamu düzeni ile ilgili zorunlu koşullardır. Mahkeme, hem davanın açıldığı günde, hem de yargılamanın her aşamasında dava şartlarının tamam olup olmadığını kendiliğinden araştırıp, inceler ve bu konuda tarafların istem ve beyanları ile bağlı değildir. Dava şartları dava açılmasından, hüküm verilmesine kadar var olmalıdır. Dava şartlarının davanın açıldığı günde bulunmaması yada bu şartlardan birinin yargılama aşamasında ortadan kalktığının öğrenilmesi durumunda mahkeme davanın mesmu (dinlenebilir) olmadığından reddetmesi gerekir.” (sinerjimevzuat.com.tr-Erişim tarihi:11.01.2018).

[24] Bilge, s. 355, 356; Üstündağ, s. 280, 281; Selçuk, s. 842; Alangoya/Yıldırım/DerenYıldırım, s. 190; Karahacıoğlu/Parlar, s. 44; Muşul, s. 100, 101; Özgenç, s. 527; Pekcanıtez/Atalay/Özekes, s. 411; Karslı, s. 393; Kuru/Arslan/Yılmaz, s. 256; Ulukap1, s. 235; Postacıoğlu/ Altay, s. 206; Görgün, s. 165; Arslan/Yılmaz/Taşpınar-Ayvaz, s. 278; Kuru, İstinaf, s. 190, 248; Tanriver, s. 622; Pekcanıtez/Özekes/Akkan/Taş-Korkmaz, s. 927; Budak/Karaaslan, s. 157, 158; Görgün/Börü/Toraman/ Kodakoğlu, s. 265, 266.

[25] Yavuz, Nihat: Hukuk Davalarında, Davalının Savunma Vasıtaları, Adalet Dergisi, S:56, Y:66, (s.638-650), s. 63; Bilge, s. 366; Alangoya/Yıldırım/Deren-Yıldırım, s. 250; Karahacioğlu/Parlar, s. 16; Muşul, s. 292; Özgenç, s. 553; Pekcanıtez/Atalay/Özekes, s. 541; Karslı, s. 405; Görgün, s. 176; Kuru, İstinaf, s. 626; Tanrıver, s. 625, 626; Pekcanıtez/Özekes/Akkan/Taş-Korkmaz, s. 1218; Budak/Karaaslan, s. 158; Görgün/ Börü/Toraman/ Kodakoğlu, s. 277. 
sürülebilir. Yetki itirazının ilk itiraz olarak kabul edilebilmesi için yetkili olduğu düşünülen mahkemenin de yapılan itirazda belirtilmesi gerekir ${ }^{[26]}$.

İşbölümü ilişkisi; asliye ticaret mahkemesi ile asliye hukuk mahkemesi arasındaki ilişkiyi düzenlemekteydi. Ancak 01.07.2012 tarihinde yürürlüğe giren $6335^{[27]}$ sayılı Kanun ile $6102^{[28]}$ sayılı TTK' nın 5. maddesi değiştirilmiş, asliye ticaret mahkemesi ile asliye hukuk mahkemesi arasındaki işbölümü ilişkisi görev ilişkisine dönüştürülmüştür. 01.07.2012 tarihinden sonra açılan davalar açısından, asliye ticaret mahkemesi ile asliye hukuk mahkemesi arasındaki işbölümü ilişkisi sona ermiştir ${ }^{[29]}$. Bunun sonucunda HMK m. 116' da bulunan işbölümü ilk itirazı artık uygulanamaz bir fikra (ölü hüküm) halini almıştır.

Taraflar arasında geçerli bir tahkim sözleşmesi mevcut ise tahkim sözleşmesinin tarafları arasında çıkmış bir uyuşmazlık konusunda, mahkemenin yargılama yaparak karar vermesi mümkün değildir. Çünkü tahkim sözleşmesiyle taraflar, aralarında çıkması muhtemel uyuşmazlığın çözümü için mahkemeye başvurmama hususunda anlaşmışlardır. Tahkim sözleşmesinin bulunmasına rağmen mahkemenin yargılama yapması halinde tahkim itirazı gündeme gelmektedir. Tahkim itirazının, davalı tarafça ilk itiraz olarak ileri sürülmesi halinde dikkate alınması gerekmektedir ${ }^{[30]}$. Çünkü tahkim ilk itiraz olmasaydı, mahkeme uyuşmazlığın esasına girecek, uyuşmazlığın çözümü konusunda bir yol kat edecek ve bu da zaman kaybina neden olacaktı.

Usule ilişkin savunma sebeplerinden dava şartlarını hâkim yargılamanın her aşamasında kendiliğinden göz önünde bulundurmak zorunda ve davalı da

[26] Bilge, s. 368; Yavuz, s. 639; Üstündağ, 488, 505; Selçuk, s. 842; Alangoya/Yıldırım/ Deren-Yıldırım, s. 244; Karahacıoğlu/Parlar, s. 16; Muşul, s. 293; Özgenç, s. 553, 554; Pekcanıtez/Atalay/Özekes, s. 541; Karslı, s. 405, 406; Ulukap1, s. 274; Umar, s. 364; Postacioğlu/Altay, s. 138, 139; Görgün, s. 176; Arslan/Yılmaz/Taşpınar-Ayvaz, s. 334; Kuru, İstinaf, s. 626; Pekcanıtez/Özekes/Akkan/Taş, s. 1219; Budak/Karaaslan, s. 158; Görgün/Börü/Toraman/ Kodakoğlu, s. 277, 278.

[27] R.G. 30.06.2012 T., S: 28339.

[28] R.G. 14.02.2011 T., S: 27846.

[29] Pekcanıtez/Atalay/Özekes, s. 542; Karslı, s. 405; Ulukap1, s. 274; Umar, s. 364; Postacioğlu/Altay, s. 452; Arslan/Yılmaz/Taşpınar-Ayvaz, s. 334; Kuru, İstinaf, s. 626; Pekcanıtez/Özekes/Akkan/Taş-Korkmaz, s. 1219; Görgün/Börü/Toraman/ Kodakoğlu, s. 278.

[30] Karahacioğlu / Parlar, s. 16; Muşul, s. 292; Özgenç, s. 554, 555; Pekcanıtez/Atalay/ Özekes, s. 542; Karslı, s. 405; Umar, s. 364; Postacioğlu/Altay, s. 252; Görgün, s. 177; Arslan/Yilmaz/Taşpınar-Ayvaz, s. 334; Ulukapı, s. 274; Kuru, İstinaf, s. 628; Pekcanıtez/Özekes/Akkan/Taş, s. 1219,1220; Budak/Karaaslan, s. 159; Görgün/ Börü/Toraman/ Kodakoğlu, s. 278. 
yargılamanın her aşamasında ileri sürebilmekteyse de ilk itirazlar ancak davaya cevap verme süresi içerisinde ileri sürülebilmektedir. Ayrıca ilk itirazlar, sslah yoluyla da ileri sürülememektedir ${ }^{[31]}$.

\section{b. Maddi Hukuka İlişskin Savunma Sebepleri}

Maddi hukuka ilişkin savunma sebepleri maddi hukuk konuları olup, diğer hukuk dallarıyla alakalıdır. Usul hukuku açısından bu savunma sebeplerinin içerikleri değil, ileri sürülme şekilleri, ileri sürülme zamanları ve usul hukukunda yarattıkları sonuç önemlidir. Maddi hukuka ilişkin savunma sebepleri, itiraz ve def' ilerdir ${ }^{[32]}$.

İtirazlar, davacının talep ettiği hakkın doğumuna engel olan veya sona ermesini sağlayan iddia veya vakıalardır. Hâkim itirazları kendiliğinden göz önünde bulundurur. Ancak hâkimin itirazları kendiliğinden göz önünde bulundurulabilmesi için itiraz sebebinin dava dosyasına girmiş olması gerekmektedir. İtiraz konusu olay davalı tarafından ileri sürülmese bile bir şekilde dava dosyasına girmişse, hâkim bu itiraz sebebini kendiliğinden göz önünde bulundurmak zorundadır ${ }^{[33]}$. İtiraz sebebi her ne kadar hâkim tarafindan kendiliğinden göz önüne alınıyorsa da itiraza ilişkin ispat yükü davalı üzerindedir. Bir hakkın doğmasına engel olan itirazlar haricindeki itirazlar, nitelikleri bakımından iddianın veya savunmanın değiştirilmesi veya genişletilmesi yasağı kapsamındadır. Bu nedenle yargılamanın her aşamasında ileri sürülemez. Bir hakkın doğmasına

[31] Üstündağ, s. 505; İnal, Nihat: Açıklamalı Hukuk Yargılama Usulü Yasası, C:1, Ankara 2003, s. 536; Zekeriya Yılmaz: Hukuk Muhakemeleri Kanunu ve Getirdiği Yeni Hükümler, Ankara 2012, s. 479; Pekcanıtez/Atalay/Özekes, s. 535; Muşul, s.292; Kılıçoğlu, Mustafa: 6100 Sayılı Hukuk Muhakemeleri Kanunu El Şerhi, İstanbul 2012, s. 625; Pekcanıtez/Atalay/Özekes, s. 541,542; Kuru/Arslan/Yılmaz, s. 268, 269; Gençcan, s. 556; Umar, s. 365; Ulukap1, s. 274; Görgün, s. 177, 178; Tutumlu, Mehmet Akif: Medeni Usul Hukukunda Islah, Ankara 2015, s. 153, 154; Bilgen, s. 381; Eroğlu, Orhan: Islah, Ankara 2017, s. 62; Görgün/Börü/Toraman/Kodakoğlu, s. 278.

[32] Ansay, Sabri Şakir: Hukuk Yargılama Usulleri, Ankara 1960, s. 246, 247; Bilge, s. 402; Selçuk, s. 845; Pekcanıtez/Atalay/Özekes, s. 535; Karslı, s. 444; Ulukapı, s. 275; Görgün, s. 214; Arslan/Yılmaz/Taşpınar-Ayvaz, s. 332; Kuru, İstinaf, s. 249; Tanrıver, s. 661; Pekcanıtez/Özekes/Akkan/Taş, s. 1208; Görgün/ Börü/Toraman/Kodakoğlu, s. 323 .

[33] Bilge, s. 402; Selçuk, s. 845, 846; Alangoya/Yıldırım/Deren-Yıldırım, s. 253; Pekcanıtez/ Atalay/Özekes, s. 535, 536; Karslı, s. 444; Kuru/Arslan/Yılmaz, s. 321; Postacioğlu/ Altay, s. 464; Ulukap1, s. 275; Görgün, s. 214; Kuru, İstinaf, s. 251; Arslan/Y1lmaz/ Taşpınar-Ayvaz, s. 333; Tanrıver, s. 661; Pekcanıtez/Özekes/Akkan/Taş-Korkmaz, s. 1208; Budak/Karaaslan, s. 173; Görgün/Börü/Toraman/Kodakoğlu, s. 323. 
engel olan itiraz sebepleri ise davalının cevap ve ikinci cevap dilekçesinden anlaşılmasa ve davalı tarafından ileri sürülmese dahi davalının daha sonra bu itirazı ileri sürmesi savunmanın değiştirilmesi veya genişletilmesi yasağı kapsamında değildir. Tahkikat bitinceye kadar ileri sürülebilir ${ }^{[34]}$.

Maddi hukuka ilişkin diğer bir savunma sebebi def' ilerdir. Def' ilerde, davalı aslında ifa ile yükümlüdür ancak özel bir sebepten dolayı ifadan kaçınma hakkına sahiptir. Def' ilerde, davalının ifa yükümlülüğünü yerine getirmemesi için kanunun kendisine tanıdığı özel bir sebebin bulunması gerekmektedir. Kural olarak itiraz bir vakıa iken, def' i bir haktır ${ }^{[35]}$. İtirazlar davalı tarafından ileri sürmese bile bir şekilde dava dosyasına girdiğinde hâkim itirazları kendiliğinden göz önünde bulunurken, def' ilerin mutlaka davalı tarafından savunmanın değiştirilmesi veya genişletilmesi yasağı başlamadan önce ileri sürülmesi gerekmektedir. Çünkü hâkim, def' ileri kendiliğinden göz önünde bulunduramaz ${ }^{[36]}$.

[34] Kuru, Baki: Hukuk Muhakemeleri Usulü, C: II, İstanbul 2001, (Kuru,Şerh), s. 1813; Postacioğlu/Altay, s. 479; Arslan/Yılmaz/Taşpınar-Ayvaz, s. 350; Kuru, İstinaf, s. 277, 278; Y.İ.B.K., 14.02.1951, 1949/17-1951/1; "Medeni Kanunumuzun üçüncü maddesi hükümlerince bir hakkın doğumu için kanunen iyi niyet şart kılınan hallerde onun vücudunun asıl olduğu esas kaidedir. Hilafını iddia eden taraf tabiatıyla ispat ile ödevlidir. Ancak işbu maddenin ikinci fikrası gereğince halin icaplarına göre kendisinden beklenen ihtimamı sarf etmemiş olmasından kanunen iyi niyet iddiasında bulunamayacak kimsenin aslın hilafı olan kötü niyeti belirmiş olduğundan bu durumda esas kaide uygulanarak kötü niyetin diğer tarafa ispat ettirilmesine sebep ve vecih kalmaz. Sabit ve mütehakkim bir hususun diğer tarafa ispat ettirilmesi cihetine gidilmesi de beyyine külfetinin tevcih suret ve tarzını düzenleyen Medeni Kanunun altıncı maddesiyle usul hükümlerine de bir veçhile aykırı düşmez." (kazanci.com-Erişim tarihi: 10.01.2018); aynı doğrultudaki diğer Yargitay kararları; Y.6.HD., 06.02.1996, E. 1995/12044, K. 1996/1068 (YKD, S:1996/8, 519-570), Y.6.HD., 21.05.1996, E. 1996/2390, K. 1996/4931 (IBBD, S:1996/10-12, s. 900); Borcu söndüren sebepler, Alman hukukunda da aynı şekilde yargılamanın sona ermesine kadar olan süreçte ileri sürülebilir. Örnek olarak takas borcu söndüren sebepler arasında yer almaktadır. Takas, davadan ayrı olarak ileri sürülmesi halinde maddi hukuk işlemi, dava içerisinde ileri sürüldüğünde ise bir usul işlemi niteliği gösterir. Jauernig, Othmar/Hess, Burkhard: Zivilprozessrecht, München 2011, s. 180, 181.

[35] Yılmaz, Ejder: Davada Takas ve Mahsup Talebi, MİHDER, 2010/2, s. 247; Pekcanıtez/ Atalay/Özekes, s. 536, 537; Pekcanıtez/Özekes/Akkan/Taş-Korkmaz, s. 1210.

[36] Bilge, s. 404; Selçuk, s. 846; Alangoya/Yıldırım/Deren-Yıldırım, s. 254; Pekcanıtez/ Atalay/Özekes, s. 536, 537; Karslı, s. 444; Kuru/Arslan/Yılmaz, s. 320; Postacığlu/ Altay, s. 466; Ulukapı, s. 275; Görgün, s. 214; Kuru, İstinaf, s. 249, 250; Tanrıver, s. 662; Arslan/Yılmaz/Taşpınar-Ayvaz, s. 332; Pekcanıtez/Özekes/Akkan/Taş-Korkmaz, s. 1210; Budak/Karaaslan, s. 173, 174; Görgün/Börü/Toraman/Kodakoğlu, s. 324. 


\section{3- Davacının Davasına Karşı Cevap Dilekçesi Verilmemesi}

Davalının, HMK m. 127 hükmü gereğince dava dilekçesinin kendisine tebliğinden itibaren iki haftalık süre içerisinde kasıtlı olarak davaya cevap dilekçesi vermemesi ya da cevap dilekçesi verme süresini ihmalle yahut bir mazeret sebebiyle kaçırması halinde; HMK m. 128 hükmü gereğince davalı, davacının ileri sürdüğü bütün vakıaları inkâr etmiş sayılır ${ }^{[37]}$. Davalı eğer bir mazereti sebebiyle süresinde cevap dilekçesi verememişse, HMK m. 95-101' e istinaden eski hale getirme talebiyle bu hakkını kullanabilir.

Davaya süresi içerisinde cevap dilekçesi vermeyen davalının sükûtu, toplumda yaygın olarak bilinen "sükût ikrardır" söyleminin aksine, inkâr mahiyetindedir. HMK m. 128' de bu hususta çıkabilecek tartışmaları önlemiştir. Davalının davaya cevap vermemiş olması, ispat külfeti açısından bir değişikliğe neden olmaz. Davacı, davalının cevap dilekçesi vermemesi halinde de, ispat yükünün yer değiştirdiği haller saklı kalmak kaydıyla, davasını dayandırdığı ve kendi lehine hak çıkarttığı olguları ispat edecektir. ${ }^{[38]}$.

\section{III- CEVAP DİLEKÇESİ, CEVAP DİLEKÇESINIIN UNSURLARI VE CEVAP VERME SÜRESI}

\section{A- Cevap Dilekçesinin Unsurları}

Cevap dilekçesinde, tıpkı dava dilekçesinde olduğu gibi bazı unsurların bulunması gerekmektedir. Cevap dilekçesinde hangi unsurların bulunması gerektiği HMK m. 129' da düzenlenmiştir. HMK m. 129 emredici mahiyette bir hükümdür ve bu nedenle maddenin aksine bir uygulama söz konusu olamaz. Cevap dilekçesinin şekli açısından ise, HMK m. 129' da belirtilen unsurları taşımak şartıyla, bir sınırlama bulunmamaktadır. Her davalı özgün bir şablon oluşturabilir.

Cevap dilekçesinde bulunması gereken birinci unsur, mahkemenin adıdır. Çünkü görevli ve yetkili mahkemenin belirlenmesi görevi davacınındır ${ }^{[39]}$. HMK

[37] Üstündağ, s. 509; Selçuk, s. 841; Alangoya/Yıldırım/Deren-Yıldırım, s. 263, 264; Karahacioğlu/Parlar, s. 126; Gençsan, s. 626; Postacıoğlu/Altay, s. 470, 471; Ulukap1, s. 268; Görgün, s. 212, 213; Kuru, İstinaf, s. 260; Tanrıver, s. 659; Pekcanıtez/Özekes/ Akkan/Taş-Korkmaz, s. 1202; Budak/Karaaslan, s. 172; Görgün/Börü/ Toraman/ Kodakoğlu, s. 321, 322.

[38] Bu konu, makalemizin IV. Bölümünde ayrıntılı olarak incelenecektir.

[39] Çelikoğlu, Cengiz Topel: Hukuk Muhakemeleri Kanununa Göre Dava ve Cevap Dilekçeleri, Terazi Hukuk Dergisi, S:63, Y:6, Kasım 2011, (s.48-60), s. 58; Şanal, s. 215; Pekcanıtez/Atalay/Özekes, s. 547; Pekcanıtez/Özekes/Akkan/Taş-Korkmaz, s. 1235. 
m. 129/1-a' da belirtilen mahkemenin adı ibaresi, içerik olarak davanın esas numarasını da kapsamaktadır. Çünkü mahkeme, cevap dilekçesinin hangi davaya ait olduğunu ancak esas numarasıyla bulabilir. Kalem personeli, taraf isimleri ile UYAP üzerinden yapacağı taramayla esas numarasına ulaşabilirse de taraflar arasında, davalının cevap dilekçesi verdiği davadan başka davalar mevcut olabilir. Özellikle taşra adliyelerinde, adliyenin bulunduğu yerin küçük ve nüfusunun az olması sebebiyle böyle karışıklıkların meydana gelmesi muhtemeldir. Eğer mahkemenin adı ve dava esas numarası cevap dilekçesinde yazılmamışsa; bu eksiklik, kalem personeli tarafından el yazısıyla tamamlanmak suretiyle dilekçe dava dosyasına girebilir ${ }^{[40]}$. Mahkemenin adı ve dava esas numarasına ilişkin eksikliğin giderilmesi amacıyla davalıya süre verilmesine gerek yoktur. Çünkü eksiklik giderilmiştir. Zaten hâkimin de dosya kapsamında cevap dilekçesini incelemesi için cevap dilekçesinin dava dosyası içerisine girmesi gerekmektedir.

HMK m. 129/1-b' de tarafların ad ve soyadları ile adreslerinin yazılması gerektiği belirtilmektedir. Davalı, cevap dilekçesinde göstereceği tarafları, davacının belirlediği taraflara göre oluşturmalıdır. Çünkü, davanın taraflarının belirlenmesi görevi davacıya aittir ${ }^{[41]}$. Davalı taraf eğer davaya cevap veriyorsa, kendisini bir vekille temsil ettirse dahi yurtiçinde bir tebligat adresi bildirmek zorundadır. Bu adreste ikamet etmesi zorunlu değildir. Davalı, her ne kadar kendisini bir vekille temsil ettirse de kendisine doğrudan tebligat yapılması gerekebilir. Örneğin, isticvap (HMK m. 171) ve yemin (HMK m. 228) gibi hallerde davalıya doğrudan tebligat yapılır ${ }^{[42]}$. Davaya hiç cevap vermemiş olan davalının, yurtiçinde bir tebligat adresi göstermemiş olması, davayı takip edebilmesi açısından bir zorunluluk değildir. Yurtdışında ikamet eden bir davalı, aleyhinde açlan davaya karşı cevap dilekçesi vermeyecekse, Türkiye’ de bir ikamet adresi bildirmek zorunda da değildir. Adresin bildirilmemiş olması, dilekçelerin teatisi aşamasından sonra inkâr kapsamında beyanlar ve örneğin, bir bilirkişi raporuna karşı itiraz dilekçesinin verilebilmesine engel teşkil etmez. Kısaca

[40] Kalem personelinin el yazısı ile davanın esas numarasını tamamlayabilmesi sonucuna, Hukuk Muhakemeleri Kanunu Yönetmeliği’nin 39. maddesinin 2. fikrası imkân vermektedir. Maddede; "Fiziken teslim alınıp elektronik ortama aktarılan veya doğrudan elektronik ortamda gelen dilekçe veya belge, hakim veya görevlendireceği personel tarafindan incelendikten sonra dosyasına aktarılır." demektedir. İnceleme yapma yetkisi olan kalem personelinin, inceleme kapsamında dilekçenin esasına ilişkin olmayan bu eksikliği gidermesinin önünde bir engel yoktur.

[41] Şanal, s. 215; Pekcanıtez/Atalay/Özekes, s. 547; Pekcanıtez/Özekes/Akkan/TaşKorkmaz, s. 1235.

[42] Pekcanıtez/Atalay/Özekes, s. 547, 548; Pekcanıtez/Özekes/Akkan/Taş-Korkmaz, s. 1236. 
kanunun lafzından çıkardığımız sonuca göre; Türkiye' de geçerli bir ikamet göstermeyen davalı, davaya cevap dilekçesi veremez ancak davayı takip edebilir.

Davalının Türkiye Cumhuriyeti kimlik numarasının cevap dilekçesinde yazılması hususu HMK m. 129/1-c’ de düzenlenmiştir. Kanunun lafzından kimlik numarasının yazılması sadece Türkiye Cumhuriyeti vatandaşlarına uygulanan bir düzenlemeymiş gibi bir sonuca ulaşllabilmekteyse de; HMK m. 129/1-c, ülkemizde ikamet eden ya da çalışan vatandaş olmayan kişilere ve özellikle ülkemizde bulunan vatansızlar ve mültecilere de uygulanmalıdır. Çünkü, turistlik amaçlı kısa bir süreliğine gelen yabancılar hariç olmak üzere, ülkemizde bulunan yabancılara da birer kimlik numarası verilmektedir ${ }^{[43]}$. Şayet bir yabancı, Türkiye' de açılan bir davada davalı sıfatını almıssa o zaman mevcut olması şartıyla kendisine verilen kimlik numarasını cevap dilekçesine yazmalıdır. Özellikle, geçici koruma kapsamına alınan Suriye Arap Cumhuriyeti'nden ülkemize gelen yabancıların bu numarayı yazmaları gerekmektedir. Çünkü, en fazla bu kişiler arasında karışıklık çıkma ihtimali vardır. Kimlik numarasının yazılmasına ilişkin düzenlemede güdülen en önemli amaç, aynı isme sahip kişiler arasında karışıklık yaşanmamasının sağlanmasıdır. Özellikle ticari şirketlerde MERSİS ${ }^{[44]}$ numarasının yazılması, her ne kadar kanunda yazılı olmasa da olması gereken hukuk (de lega ferenda) açısından gereklidir. Çünkü tüzel kişilerde de isim benzerliği sebebiyle birçok sorun yaşanmaktadır.

HMK m. 129/1-ç' de; varsa tarafların kanuni temsilcilerinin ve davacı vekilinin adı, soyadı ve adreslerinin yazılması gerektiği bildirilmiştir. Davacı veya davalı, davayı bir vekil vasıtasıyla takip etmek zorunda değildir. Taraflar

[43] “ 04/04/2013 tarihli ve 6458 sayılı Yabancilar ve Uluslararası Koruma Kanununun "Geçici Koruma" başlıklı 91 inci maddesi hükmü gereğince hazırlanan Geçici Koruma Yönetmeliği 22 Ekim 2014 tarihli ve 29153 sayılı Resmi Gazete'de yayımlanarak yürürlüğe girmiştir. Söz konusu Yönetmeliğin GEÇİCİ 1 inci Maddesinin birinci fıkrası gereği; Suriye Arap Cumhuriyetinden ülkemize gelen Suriyeliler ile vatansızlar ve mülteciler geçici koruma kapsamına alınmışlardır. 22/10/2014 tarihli ve 6883 sayılı Geçici Koruma Yönetmeliğinin "Geçici Koruma Kimlik Belgesi” başlıklı 22 nci maddesi gereğince, kayıt işlemleri tamamlananlara, valilikler tarafından geçici koruma kimlik belgesi düzenlenmekte ve bu yabancilara 25/04/2006 tarihli ve 5490 sayılı Kanun ile 22/10/2014 tarihli ve 6883 sayılı Geçici Koruma Yönetmeliği kapsamında yabancı kimlik numarası tahsis edilmektedir." (www.goc.gov.tr-Erişim tarihi: 12.01.2018).

[44] "Merkezi Sicil Kayıt Sistemi yani MERSİS, ticaret yapan tüzel kişilerin tüm kayıtlarının bir yerde tutulması ve bu kayıtların diğer ticaret yapan kişilerle paylaşılmasına yarayan bir sistemdir. Gümrük ve Ticaret Bakanlığı tarafından desteklenen ve hayata geçirilen bir sistemdir. Ticaret yapan her firmanın 16 haneli kendine özgü bir MERSİS numarası vardır. Bu 16 haneli numara ile Gümrük ve Ticaret Bakanlığının sitesine giriş yaparak sorgulama yapabilir." (www. mersis.org-Erişim tarihi:12.01.2018). 
davayı kendileri de takip edebilir. Eğer davanın taraflarına bir vasi ya da kayyum atanmış ise, o zaman bu vasi ya da kayyumun da ad, soyad ve adreslerinin cevap dilekçesine yazılması zorunludur ${ }^{[45]}$. Kanuni temsilci veya vekilin cevap dilekçesine yazılmasındaki en önemli amaç, dava ile ilgili tebligatların bu kişilere yapılacak olmasıdır. Tarafın bir vasisi, kayyumu yahut vekilinin olduğu dosya içeriğinden anlaşılabilirr ${ }^{[46]}$. Ancak bunun cevap dilekçesine yazılması mahkemenin işini kolaylaştırır mahiyettedir. Vekil ile takip edilen bir dosyada tebligatlar asile gönderilemez ${ }^{[4]]}$.

HMK m. 129/1-d uyarınca davalı, cevap dilekçesinde savunmasının dayanağı olan vakıaların açık özetlerini, sıra numarası alıında yazmalıdır. Davalı, savunmasına dayanak yaptığı vakıaları yazarken kronolojik bir sıralama yapabilir. Usulü itirazlarını önce, maddi hukuka ilişkin itirazlarını ise sonra yazabilir. Ancak böyle bir sıralama yapılması açısından zorunluluk bulunmamaktadır. Çünkü, hâkimin tüm dilekçeleri baştan sona okuma ve dosyayı ayrıntılı olarak inceleme yükümlülüğü bulunmaktadır. Cevap dilekçesinin tamamını okuyan bir hâkim açısından usulü itirazların, maddi hukuka ilişkin itirazlardan sonra yazılmış olmasının bir önemi bulunmamaktadır. Hâkim, HMK m. 25 hükmü gereğince

[45] Karslı/Koç/Konuralp, cevap dilekçesi verilirken davalının sadece davacının vekilinin ad, soyad ve adresinin değil, varsa kendi vekilinin ad, soyad ve adresinin belirtilmesi gerektiği, HMK m. 129/1-ç bendinde ikinci kısım düzenlenirken bu hususun gözden kaçırıldığı yönünde görüş bildirmiştir. Karslı, Abdurrahim/Koç, Evren/Konuralp, Cengiz Serhat: Hukuk Muhakemeleri Kanunu’nda Problemli Konular, İstanbul 2014, s. 92.

[46] Umar, dosyada tarafların vekâleti olduğu için, vekillerin isim ve adreslerinin yazılmasının zorunlu olmadığını ileri sürmüştür. Umar, s. 420; Karslı ise, dava dosyası bir vekille takip ediliyorsa, vekilin yazılmasının zorunlu olduğunu, bu husus kanunda yazılı olmasaydı bile vekilin adının, soyadının ve adresinin yazılmasının gerekli olduğunu ileri sürmüştür. Karslı, s. 446; Pekcanıtez /Özekes/Akkan/Taş-Korkmaz, bu hususun kanunda yazılı olmasından dolayı cevap dilekçesinde yazılmasının zorunlu olduğunu ileri sürmüştür. Pekcanıtez/Özekes/Akkan/Taş-Korkmaz, s. 1237.

[47] Y. 8. HD., 30.05.2016, E. 2016/7148, K. 2016/9420; "HMK'nun 73, 81, 82, 83, Avukatlık Kanunu'nun 41., Tebligat Kanunu’nun 11. maddeleri gereğince vekille takip edilen işlerde vekile tebligat zorunludur. Anılan bu düzenlemeler gereğince tebligatın vekile yapılması ile yasal süreler işlemeye başlar, yine bu tarihe göre takip kesinleştirilerek takibe devam işlemleri yapılır. Ne var ki vekile tebliğ zorunluluğunun bulunması asile tebligat yapılması lüzumunu ortadan kaldırmaz. Şöyle ki, 2004 Sayılı İcra-İflas Kanunu’nun 76. maddesinde mal beyanında bulunmamak suçu, 338. maddesinde düzenlenen hakikate muhalif beyanda bulunma suçu gibi icra-iflas suçlarında borçlunun cezalandırılabilmesi için icra emrinin borçlunun vekiline değil, kendisine tebliğ edilmiş olması gerekir. (Prof. Dr. Baki Kuru, Hukuk Muhakemeleri Usulü, 6. baskı, cilt 2, sh: 1280) Cezaların şahsiliği kuralı gereğince borçlu asilin cezai yönden sorumlu tutulabilmesi için icra emrinin borçlu asile tebliği zorunludur." (kazanci.com.tr-Erişim tarihi:12.01.2018). 
davalının dilekçesinde bildirmediği vakıaları kendiliğinden inceleyemez ${ }^{[48]}$. Bu nedenle davalının hem davacının davasında ileri sürdügü vakıalara cevap hem de savunmasını güçlendirecek yeni vakıalar ileri sürmesi kaçınılmazdır.

Davalı HMK m. 129/1-e hükmü gereğince cevap dilekçesinde ileri sürdüğü vakıaların, hangi deliller ile ispat edileceğini açıcça belirtmelidir. Davalı, cevap dilekçesinde herhangi bir vakıayı yazıp açıkladıktan sonra, vakıanın ispatına ilişkin delili de bildirmelidir. Davalının ayrıca delillerini cevap dilekçesinin sonunda bir liste halinde sunması; dayandığı delile karşı davacının iddiada bulunması, mahkemenin delillerini dikkate alması ve davalı için belirlenecek delil avansının tespiti açısından gereklidir. Davalı mevcut delillerini, cevap dilekçesi ile birlikte tebliğ edilmesi için, davadaki karşı taraf sayısından bir fazla surette mahkemeye sunar. Bu ekler hiçbir harca tabi değildir. Eğer başka yerlerden getirilmesi gerekli olan deliller varsa (örneğin, bir tapu kaydının ilgili tapu müdürlüğünden getirilmesi gibi) bu delillerin mahkeme dosyasının içerisine nasıl getirileceğini açıklamalıdır.

Davalı, kendisinin haklı olduğuna karar verilmesini gerektiren hukuki sebepleri de HMK m. 129/1-f hükmü uyarınca dilekçesinde belirtebilir. Ancak bu zorunlu değildir ${ }^{[49]}$. Çünkü HMK m. 33' e istinaden hâkim, tarafların bildirdiği hukuki sebeplerle bağlı olmayıp, davaya uygulanacak hukuk kuralını kendiliğinden bulmak ve uygulamakla yükümlüdür.

Davalı, HMK m. 129/1-g hükmü gereğince cevap dilekçesinde belirttiği vakıalara bağlı olarak, davanın sonunda kendi ile ilgili ne karar verilmesini istiyorsa talep sonucunda bunu belirtmelidir. Davalı, talep sonucunda; davanın usulden veya esastan tamamen veya kısmen reddini, davanın tamamen veya kısmen kabulünü, davanın açılmamış sayılmasına karar verilmesini talep edebilir. Eğer davalı talep sonucunu açıç̧a belirtmedi ise, dilekçesinin kapsamından davanın sonunda ne yönde karar verilmesini istediği zımnen anlaşılabilir. $\mathrm{Bu}$ nedenle, talep sonucunun cevap dilekçesinde belirtilmesi zorunlu değildir ${ }^{[50]}$.

[48] Kuru, Şerh, C:II, s. 1760; Çelikoğlu, s. 59; Pekcanıtez/Atalay/Özekes, s. 548, 549; Ulukapı, s. 272; Arslan/Yılmaz/Taşpınar-Ayvaz, s. 335; Yılmaz, Ejder: Hukuk Muhakemeleri Kanunu Şerhi, Ankara 2016, s. 862; Kuru, İstinaf, s. 253, 254; Tanriver, s. 663, 664; Pekcanıtez/Özekes/Akkan/Taş-Korkmaz, s. 1238.

[49] Kuru, Şerh, C:II, s. 1760; Çelikoğlu, s. 60; Pekcanıtez/Atalay/Özekes, s. 549; Postacioğlu/Altay, s. 448; Ulukapı, s. 270; Umar, s. 421; Tanrıver, s. 665; Kuru, Baki: Medeni Usul Hukuku, İstanbul 2015, s. 177, 178; Kuru, İstinaf, s. 255, 256; Pekcanıtez/Özekes/Akkan/Taş-Korkmaz, s. 1239.

[50] Umar, davalının talep sonucu bölümünde, davanın kısmen veya tamamen reddini talep etmese de hâkimin davanın sonunda davayı kısmen veya tamamen reddedebileceğini ileri sürmektedir. Umar, s. 418, 419; Uygulamada da tarafların dilekçelerinin kapsamından 
Davalının ya da varsa vekili veya kanuni temsilcisinin cevap dilekçesini HMK m. 129/1-ğ hükmü uyarınca imzalaması germektedir. Eğer vekil, cevap dilekçesini UYAP üzerinden gönderiyorsa o zaman elektronik imza yoluyla da imzalayabilir. Islak imzalı bir dilekçe ile elektronik imzayla imzalanmış bir dilekçe arasında fark bulunmamaktadır.

\section{B- Cevap Dilekçesinin Unsurlarında Eksiklik Bulunması}

Cevap dilekçesinde bulunması gereken unsurlar dokuz tane olup, bu unsurların hepsinin cevap dilekçesinde bulunması zorunlu değildir. Dokuz unsurdan beş tanesinin cevap dilekçesinde bulunması zorunlu iken, kalan dört unsur davalının isteğine bağlı olarak cevap dilekçesine eklenebilir. HMK m. 130' a göre; mahkemenin adı (HMK m. 129/1-a), tarafların ad ve soyadları ile adresleri ve yurtiçindeki tebligat adresi (HMK m. 129/1-b), davalının Türkiye Cumhuriyeti kimlik numarası (HMK m. 129/1-c), varsa tarafların kanuni temsilcilerinin veya vekilinin adı, soyadı ve adresleri (HMK m. 129/1-ç), davalının ya da kanuni temsilcisinin yahut vekilinin imzasının (HMK m. 129/1-ğ) cevap dilekçesinde bulunmass zorunludur.

Cevap dilekçesi, bulunması zorunlu olan unsurlardan bir ya da birden fazlasını ihtiva etmiyorsa, hâkim eksikliğin giderilmesi için davalıya bir hafta kesin süre verir ${ }^{[51]}$. Bu süre tebliğden itibaren işlemeye başlar. Eğer davalı, bu

davanın kabulünü mü reddini mi istedikleri anlaşılır. Eğer bir davada, talep sonucu yoksa ve davalının cevap dilekçesinden de davanın sonunda kendi için ne istediği anlaşılamıyorsa, hâkimin HMK m. 31 hükmü uyarınca davayı aydınlatma ödevi kapsamında davalıya talep sonucunu açıklattırması gerekir.

[51] Yılmaz, HMK m. 119/2' de belirtilen sürenin kesin olarak belirtildiğini; ancak HMK m. 130 ' da düzenlenen sürenin bu şekilde nitelendirilmediğini ifade etmiştir. Yılmaz, Şerh, s. 863, 864. Yılmaz, bazı eserlerinde ise sürenin kesin olduğu yönünde görüş bildirmiştir, Yılmaz, Ejder: Hukuk Muhakemeleri Kanununun Getirdikleri, Ankara Barosu Dergisi 2011/2,(s.236-253), s. 236. Oysa HMK m. 94/1' e göre kanunun belirlediği süreler kesindir. Bu nedenle HMK m. 130' daki süre HMK m. 94/1' e göre kesin bir süredir. Kanımca HMK m. 119/2' deki kesin ibaresi fazladan konulmuş bir ibaredir. Kanun'un genel gerekçesinde; "Cevap dilekçesinde yer alması gereken hususların eksikliği hâlinde, nasıl hareket edileceğini düzenleyen bu madde, cevap dilekçesinin bütün unsurları bakımından değil, sadece (a), (b), (c), (ç) ve (乌̆) bentlerinde belirtilen hususların eksikliği hâlinde, hâkimin, yedi günlük süre vermesini, eksikliğin bu süre zarfinda giderilmemesi durumunda ise cevap dilekçesinin verilmemişs sayılması müeyyidesi ile karşılaşılacağını öngörmektedir." demektedir ( Hukuk Muhakemeleri Kanunu Tasarısı ve Adalet Komisyonu Raporu (1/574), Türkiye Büyük Millet Meclisi, S. Sayısı: 393 ). Gerekçede de bir haftalık süre zarfında cevap dilekçesindeki eksikliğin giderilmemesi durumunda, cevap dilekçesinin verilmemiş sayılması müeyyidesi ile karşılaşılacağı belirtilmiştir. 
bir haftalık kesin süre içerisinde zorunlu unsurları ihtiva eden cevap dilekçesini mahkemeye sunmazsa, davaya cevap vermemiş kabul edilir. Cevap dilekçesinde bulunması zorunlu olmayan diğer unsurlar ise davalının lehine karar verilmesini sağlamaya yönelik unsurlardır. Çünkü davalı vakıaları, bu vakıaların ispatına ilişkin delilleri ve hukuki sebepleri cevap dilekçesinde bildirmemişse, davacının iddialarını çürütemeyecek ve hatta açılmış olan dava belki bu nedenle aleyhine sonuçlanacaktır ${ }^{[52]}$.

\section{C- Cevap Dilekçesi Verme Süresi}

Kural olarak HMK m. 127' ye istinaden davaya cevap verme süresi, dava dilekçesinin davalıya tebliğinden itibaren iki haftadır. Hâkim, HMK m. 90/1 hükmü uyarınca kanunda belirtilen süreleri istisnai durumlar dışında artıramaz veya eksiltemez. Davaya cevap verme süresini hâkimin artırması ya da eksiltmesi için bir gerekçesinin olması gerekir. Hâkimin bu gerekçeye istinaden de bir ara karar ihdas etmesi lazımdır. Yazılı yargılama usulü uygulanan davalarda cevap verme süresi adli tatile denk geliyorsa bu süre, adli tatilin bitiminden itibaren bir hafta uzar.

Davaya cevap verme süresi olan iki haftalık süre içerisinde eğer davalı cevap dilekçesi verdiyse, kalan süre içerisinde ayrı bir dilekçe ile esasa ilişkin başkaca itiraz veya vakıaları ileri sürebiliir ${ }^{[33]}$. Ancak cevap dilekçesi verildikten sonra usule ilişkin ilk itirazlar HMK m. 131 hükmü gereğince ileri sürülemez. Zaten HMK m. 131' in gerekçesinde de usulü itirazların ancak cevap dilekçesi ile ileri sürülebileceği bildirilmektedir.

Davalı eğer davaya cevap verme süresi olan iki haftalık süre içerisinde cevap dilekçesini hazırlayamayacağını düşünüyorsa, mahkemeden davaya cevap verme süresi içerisinde, bir defaya mahsus olmak üzere ek bir süre talep edebilir ${ }^{[54]}$.

[52] Pekcanıtez/Atalay/Özekes, s. 550; Postacioğlu/Altay, s. 449; Umar, s. 421; Kuru, Usul, s. 181; Tanrıver, s. 667; Pekcanıtez/Özekes/Akkan/Taş-Korkmaz, s. 1241.

[53] Pekcanıtez/Atalay/Özekes, s. 247; Y.H.G.K., 13.10.2010, E. 2010/15-407, K. 2010/501; "Davalı, yetki itirazını, ancak esasa cevap süresi içinde vereceği cevap lâyihasında (esasa cevapları ile birlikte) bildirebilir (md. 195/I). Daha açık ifadeyle, davalı cevap lâyihasında (varsa) yetki itirazını (ve diğer ilk itirazlarını) ve esasa cevabını birlikte bildirmek zorunda olup; cevap lâyihasında önce esasa ilişkin cevaplarını, sonra yetki itirazını bildirmiş olsa bile, yetki itirazı süresinde yapılmış sayılır, yani geçerlidir." (kararara.com-Erişim tarihi:14.01.2018).

[54] Ek süre talebi sadece davaya cevap dilekçesi açısından geçerli olup, ikinci cevap dilekçesi için ek süre talep edilemez ve ayrıca davaya cevap dilekçesinin verilmesine ilişkin ek süre, ikinci cevap dilekçesinin verilmesine ilişkin süreyi de aynı uzunlukta uzatmaz. İkinci cevap 
Mahkemece verilecek ek süre en fazla; yazılı yargılama usulünde HMK m. 127’ ye istinaden bir ayı, basit yargılama usulünde ise HMK m. 317’ e istinaden iki haftayı geçemez. Hâkim, verilecek süreyi belirlerken davalının gerekçesini dikkate almalı, süreyi bu gerekçeye göre belirlemelidir. Davalı neden ek süre istediğini, ek süre talebine ilişkin dilekçesinde belirtmeli ve ek süre talebine ilişkin gerekçesini de yaklaşık olarak ispat etmelidir. Kanun'un lafzına göre verilen ek süre, cevap dilekçesi verme süresine eklenecek bir süredir. Ek süre talebinin değerlendirilmesi sonucunda verilecek ara karar taraflara tebliğ edilir. Ancak ek sürenin cevap verme süresinden sonra davalıya tebliğ edilmesi halinde ek süre, tebliğ tarihinden itibaren işlemeye başlamaz. Bu süre davaya cevap verme süresine eklenir ${ }^{[55]}$.

dilekçesi verme süresi HMK m. 136/1' e göre iki haftadır. Bu konu ile ilgili çalışmamızda açıklama yapılmıştır. Gerekçemiz için bakınız; § II. Savunma Hakkı ve Savunmanın Şekli, B. Savunmanın Şekli, 2. Davacının Davasına Karşı Cevap Dilekçesi Verilmesi.

[55] Pekcanıtez/Özekes/Akkan/Taş-Korkmaz, Tanrıver ve Tutumlu, ek sürenin tebliğden itibaren başlaması gerektiği görüşündedir. Tutumlu, Mehmet Akif: Ek Cevap Süresinin Verilme Koşulları, Başlangıç Tarihi ve Hesaplanması, Terazi Hukuk Dergisi, C:11, S:123, Kasım 2016, (s.106-108), s. 108; Tanrıver, s. 669; Pekcanıtez/Özekes/Akkan/Taş-Korkmaz, s. 1246; Bu yönde Yargıtay kararları; Y.23.HD., 23.11.2015, E. 2015/332, K. 2015/7522; "Dava dilekçesi, davalı tarafa 06.03.2012 tarihinde ve iki haftalık kesin süre içerisinde cevap hakkı tanınacağına dair meşruhatı ihtiva eder şekilde tebliğ edildiği, davalı tarafın 19.03.2012 tarihinde ve süresinde gerekçeleri de belirtilmek sureti ile bir aylık ek süre talep ettiği, hakim tarafından dilekçe üzerine iki hafta uzatılmasına dair ibarenin yazıldığı, ancak ek sürenin hangi tarihten itibaren başlayacağının belirtilmediği, çıkartılan tebligatta ise "19.03.2012 havale tarihli süre uzatım dilekçesinin kabulü ile tarafınıza cevap verme süresinin bitiminden itibaren iki hafta süre verilerek süreniz uzatılmıştır." ibaresinin yazılı olduğu ve 04.04.2012 tarihinde tebliğ edildiği anlaşılmıştır. HMK'nın ilgili maddesinin çıkarılış amacına göre, bu hususun karşı tarafa tebliğ tarihinden itibaren başlayacağının kabulü gerekir. Mahkemece bu husus gözardı edilerek cevap dilekçesinin süre geçtiğinden bahisle yok sayılması doğru olmadığı gibi, zamanaşımı ile ilgili talebin de cevap dilekçesi süresinde verilmediğinden bahisle dikkate alınmaması doğru olmamıştır."; Y.17.HD., 01.04.2014, E. 2014/1397, K. 2014/4821; Y.15.HD., 14.09.2017, E. 2017/1302, K. 2017/2995 (sinerjimevzuat.com.tr- Erişim tarihi:14.01.2018). Karşı görüşte olan yazar; Pekcanıtez/Atalay/Özekes, s. 552, 553; Kuru/Arslan/Yılmaz, s. 327; Arslan/Yılmaz/ Taşpınar-Ayvaz, s. 338; Karşı görüş yönünde Yargıtay kararları; Y.15.HD., 29.01.2016, E. 2015/6312, K. 2016/542; " Şayet mahkemece, verilen ek sürenin ne zaman sona ereceği belirtilmemişse bu ek süre, kanuni cevap süresi olan iki haftalık sürenin sona ermesiyle başlar”; Y.3.HD., 06.05.1999, E. 1999/4323, K. 1999/4677. Ancak yargılamayı uzatmak isteyen bir davalının, davaya cevap verme süresinin sonunda başvurması hali ve kararın verilmesi ile tebliğ usulü ele alındığında, bu sürenin neredeyse iki aya kadar uzayabileceği dikkate alınmalıdır. Mahkemeden ek süre talep eden bir davalının, yine aynı şekilde kararın verilip verilmediğini mahkeme kaleminden takip etmesi gerekir. 
Mahkemece ek süre talebinin reddedilmesi ve davaya cevap verme süresinin geçmesi halinde davalı, davaya cevap dilekçesi ile ancak kullanabileceği bazı haklarını kullanmaktan mahrum kalabilir. Uygulamada mahkemeden ek süre talep eden davalılar talep dilekçelerinde, ancak davaya cevap dilekçesi ile kullanabileceği hakları (ilk itirazlar ve karşı dava vb.), talebin reddedilme ihtimaline istinaden, ayrıca bildirmektedir. Ancak bu bir zorunluluk değildir. Davalı ek süre talebine ilişkin dilekçede davaya cevap dilekçesi ile kullanabileceği bu hakları bildirmemişse, ret kararı üzerine bu haklarını kullanması için davalıya ek bir süre verilemez. Çünkü HMK m. 127’ de böyle bir düzenleme bulunmamakta ve kanunun lafżından da böyle bir sonuç çıkmamaktadır ${ }^{[56]}$.

\section{IV- CEVAP DİLEKÇESİ VERILLMEMESINIIN SONUÇLARI}

\section{A- Cevap Dilekçesi Verilmemesinin Davacı Açısından Sonuçları}

Davalının süresi içerisinde davaya cevap vermemesi halinde oluşacak sonuçlar, HMK m. 128' de düzenlenmiştir. Söz konusu maddenin lafzına göre davalının cevap dilekçesi vermemesi halinde, davacının dava dilekçesinde ileri sürdüğü tüm vakıaları inkâr etmiş sayılacağı sonucunun doğacağı yazmaktadır. İlgili madde incelendiğinde sadece davalı açısından sonuçların yazılmış olduğu düşünülse de bu durumun, davacı açısından da bazı sonuçlar doğurması kaçınılmazdır.

[56] Pekcanıtez/Özekes/Akkan/Taş-Korkmaz, davalıya ret kararı ile birlikte davaya cevap süresinin geçmesi halinde ilk itiraz, karşı dava, itiraz ve def' ileri için hak kaybına uğramaması açısından kısa bir süre verilmesi gerektiği görüşündedir. Pekcanıtez/Özekes/ Akkan/Taş-Korkmaz, s. 1246. Oysa böyle bir sürenin verilmesi talebi reddedilen davalıya yine de ek sürenin verilmesi anlamına gelir ki bu da ret kararının uygulanmasını ve amacını önler mahiyettedir. Mahkemeden ek süre talep eden bir davalının, böyle durumları ön görmesi ve talebini dava dilekçesinin kendisine tebliğ edilmesi üzerine derhal mahkemeye sunması gerekir. Aksi bir durum davacı açısından hakkaniyete aykırı bir sonuç doğurur. Çünkü davalı bu yolla dolaylı olarak amacına ulaşmış olur. Y.19.HD., 25.06.2015, E. 2014/19729, K. 2015/9448; "Dava dosyasının incelenmesinden, dava dilekçesinin davalı şirkete 11.03.2014 tarihinde tebliğ edildiği, davalı şirket vekilinin 13.03.2014 havale tarihli dilekçesi ile mahkemeden cevap süresinin uzatılmasını talep ettiği, bu dilekçesinde herhangi bir yetki itirazında bulunmadığı, mahkemenin 14.03.2014 tarihli ara kararı ile davalının cevap verme süresinin sürenin dolduğu tarihten başlamak üzere bir ay süre ile uzatılmasına karar verildiği, bu ara kararın davalı vekiline 20.03.2014 tarihinde davalı vekiline tebliğ edildiği, davalı vekili tarafından verilen "davayı cevaptır" konulu, 25.03.2014 havale tarihli dilekçe ile cevapların sunulduğu ve fakat bu dilekçede herhangi bir yetki itirazında bulunulmadığı, ayrı olarak verilen 03.04.2014 havale tarihli dilekçe ile yetki itirazında bulunulduğu anlaşılmıştır. Davalı süresi içinde yetki itirazında bulunmamıştır. Buna göre, mahkemece davalının yetki itirazının reddine karar verilmesi gerekirken, yazılı şekilde yetki itirazının kabulü ile yetkisizlik kararı verilmesi doğru değildir." (kararara. com-Erişim tarihi:14.01.2018). 
Yazılı yargılama usulünde dilekçeler aşaması; dava dilekçesi, cevap dilekçesi, cevaba cevap dilekçesi ve ikinci cevap dilekçesi olmak üzere dört aşamadan oluşmaktadır. Basit yargılama usulünde ise dilekçeler aşaması; dava dilekçesi ve cevap dilekçesi olmak üzere iki aşamadan oluşmaktadır. Yazılı yargılama usulünde tarafların dava ve cevap dilekçesi haricinde ikinci bir dilekçe hakları daha vardır ki taraflar, bu ikinci dilekçelerinde iddialarını veya savunmalarını diledikleri şekilde değiştirebilir yahut genişletebilir. Oysa, davalının davaya cevap vermemesi halinde, davacının da cevaba cevap dilekçesi verme hakkı ortadan kalkacaktır. Çünkü HMK m. 136' ya göre davacı, cevap dilekçesinin kendisine tebliğini müteakip iki hafta içerisinde cevaba cevap dilekçesi verebilir. Kanunun lafzı incelendiğinde de görüleceği üzere davacının cevaba cevap dilekçesi verebilmesinin şartı, kendisine cevap dilekçesinin tebliğ edilmesidir. Eğer davalı davaya cevap dilekçesi vermezse, davacıya da herhangi bir tebligat yapılmayacaktır. Bu nedenle yazılı yargılama usulünün uygulandığı davalarda, davalının davaya cevap dilekçesi vermemesi halinde davacının da cevaba cevap dilekçesi verme hakkı ortadan kalkmış olacaktır ${ }^{[57]}$. Basit yargılama usulünde ise tarafların ikinci bir dilekçe verme hakları olmadığı için böyle bir sorun söz konusu değildir.

Davalının cevap dilekçesi vermemesi halinde doğacak bir başka sonuç; görülmekte olan davanın, davacı tarafından dava açarken sunmuş olduğu vakıalar ve deliller esas alınarak görülüp sonuçlanacak olmasıdır. Çünkü davalı cevap dilekçesi vermediği için, HMK m. 145 hükümleri saklı kalmak kaydıyla, artık bir delil listesi sunamayacaktır. Yargitay Hukuk Genel Kurulu, 20.04.2016 tarih, E. 2014/2-695, K. 2016/522 sayılı kararında; süresi içerisinde davaya cevap vermeyen davalının, kötüye kullanılmadıkça davacı tarafın ileri sürdüğ̈̈ vakıaları çürütmek amacı ile delil bildirip bildiremeyeceği, cevap dilekçesi ile birlikte delil bildirmeyen davalıya ön inceleme duruşmasında delil bildirmesi için süre verilmesinin gerekip gerekmediği hususlarını incelemiştir. YHGK, bu hususları incelerken AİHS m. 6 ' da yer alan adil yargılanma hakkına atı yapmış ve bu ilkenin en önemli unsurlarından birinin de yargilamanın makul sürede bitirilmesi olduğunu açıklamıştır. Bunun yanı sıra, tarafların, diğer taraf karşısında kendini dezavantajı konuma sokmayacak şekilde iddiasını mahkemeye sunabilmesi için makul fırsata sahip olmaları gerektiğine de değinmiştir. YHGK'

[57] HMK m. 137 hükmü, dilekçelerin karşılıklı olarak verilmesinden sonra ön incelemenin yapılacağını bildirilmektedir. Yargılamayı yapan mahkeme de davalının cevap dilekçesi verme süresi içerisinde cevap dilekçesi vermediğini tespit ettiği anda, hemen bir ön inceleme duruşması günü tayin edecektir. Bu nedenle davacının ek bir dilekçe vereceği zaman aralığı da bulunmamaktadır. Çünkü hâkimin ön inceleme aşamasına geçmesi, dilekçelerin teatisi aşamasının son bulduğunu tespit ettiği andır. 
nın süresinde cevap dilekçesi vermeyerek delillerini bildirmeyen davalının, yasal süre geçtikten sonra delil bildiremeyeceği yönündeki kararının esas gerekçesi ise delillerin gösterilmesinin dilekçelerin teatisi aşamasına hasredilmiş olması, tarafların kanunda belirtilen sürelerden sonra delil gösterebilmelerinin ancak HMK m. 141 ve 145. maddelerde düzenlenen hallerde mümkün olduğudur ${ }^{[58]}$.

Doktrinde, cevap dilekçesi sunmayan davalının sonradan delil listesi sunabileceği yönünde görüşler mevcuttur ${ }^{[59]}$. Ancak YHGK, süresi içerisinde cevap dilekçesi verilmemesi halinde delil listesi sunulamayacağını açıkça ortaya koy-

[58] YHGK, 20.04.2016, E. 2014/2-695, K. 2016/522; “6100 HMK’nın sistematiği içinde; tahkikat aşamasına geçilmezden evvel tarafların uyuşmazlık konularının ve bu uyuşmazlıkların çözümü için ileri sürdükleri delillerin daha işin en başında belirlenerek tahkikatın etkin bir şekilde yapılmasının hedeflendiği anlaşılmaktadır. Bu itibarla, yukarıda ayrıntılı olarak açıklanan hususların özetlenmesi gerekirse; AİHS'nin 6. Maddesinde düzenlenen adil yargılamanın etkin ve makul bir süre içerisinde bitirilmesi için 6100 sayılı HMK'da düzenlemelere yer verilmiş olup, bu bağlamda delil gösterilmesi dilekçelerin teatisi (dava, cevap, cevaba cevap ve ikinci cevap) aşamasına hasredilmiştir. Tarafların, kanunda belirtilen bu sürelerden sonra delil gösterebilmeleri ancak iki yasa maddesinde belirtilen hallerde sınırlıdır. Onlarda; iddia ve savunmanın genişletilmesi veya değiştirilmesini düzenleyen 141. Madde ile sonradan delil gösterilmesinin hüküm altına alındığı 145. Maddedeki durumlardır. Bu açıklamalar ışı̆̆ında somut olay incelendiğinde; davalının cevap dilekçesi vermediği hususunda bir tartışma bulunmamaktadır. Dava dilekçesinin usule uygun ihtar içerir şekilde tebliğinden sonra iki haftalık süre içerisinde delillerini bildirmeyen davalının sonradan delil gösterebilmesi için HMK'nın 145. Maddesinde belirtilen istisnai hallerin mevcudiyeti de somut olayda ileri sürülmüş değildir. İddia ve savunmanın genişletilmesi veya değiştirilmesini düzenleyen 141. Madde koşulları da oluşmamıştır. Kaldı ki somut olayda davalı, cevap ve delil bildirmek için mehil talebini 18.09.2012 tarihli ön inceleme duruşmasından sonra tahkikat aşamasında 02.11.2012 tarihli duruşmada ileri sürmüştür. Bu durumda dava dilekçesinin davalıya 31.05.2012 tarihinde usulüne uygun bir şekilde tebliğ edilmesinden sonra süresi içerisinde cevap dilekçesi verilmediğinden savunmanın dayanağı olarak süresinde ileri sürülen bir delil (HMK m. 129/1-e) bulunmadığından yerel mahkemenin davalıya delil göstermesi için süre vermesini yasal olarak imkân bulunmadığının kabulü gerekir." (sinerjimevzuat. com- Erişim tarihi: 18.01.2018).

[59] Tutumlu, karşı ispat açısından ve delillerin cevap dilekçesinde belirtilmesinin zorunlu unsur olmamasından dolayı, davalının delil listesi sunmasına müsaade edilmesi gerektiği görüşündedir. Tutumlu, Mehmet Akif: Cevap Dilekçesi Vermeyen Davalının Delil Gösterme Hakkı Düşer mi?, Terazi Aylık Hukuk Dergisi, C:11, S:120, Ağustos 2016, (s.134-138), s. 138; Tutumlu, Mehmet Akif: Cevap Dilekçesinde Gösterilmeyen Delile (Tanık) Tahkikat Aşamasında Dayanılabilir mi?, Terazi Aylık Hukuk Dergisi, C:9, S:95, Temmuz 2014, (s.116-118), s. 118; Tutumlu, Mehmet Akif: Medeni Yargilama Hukukunda Delillerin İleri Sürülmesi, Ankara 2007, s. 51; Tutumlu ile aynı görüşte olan yazar; Aras, s. 1940; Tutumlu, her ne kadar davalının karşı ispat açısından delil sunma hakkının olması gerektiği görüşünde ise HMK' da delil sunulmasına ilişkin düzenlemelere ve iddianın veya savunmanın değiştirilmesi veya genişletilmesi yasağı kapsamına göre 
muştur. Söz konusu karar ışığında bir değerlendirme yapmak gerekirse; HMK m. 128 hükmü gereğince, davaya yasal süresi içerisinde cevap dilekçesi vermeyen davalı, davacının dava dilekçesinde ileri sürmüş olduğu vakıaların tamamını inkâr etmiş kabul edilecektir. Taraflara, dilekçelerinde göstermiş oldukları; ancak henüz dava dosyasına sunmadıkları delillerini sunmaları için HMK m. 140/5 hükmü gereğince iki haftalık kesin süre verilmesi mümkündür. Ancak HMK m. 140/5' de "dilekçelerinde gösterdikleri" ibaresi kullanılmışır. Bu nedenle cevap dilekçesi sunmayan davalı, HMK m. 140/5' ten faydalanamayacaktır. Çünkü cevap dilekçesinin sunulmaması aynı zamanda delil gösterilmemiş olmasını da ifade etmektedir. Kanun koyucu, HMK m. 145 ile tarafların belirtilen sürelerden sonra delil gösteremeyeceğini emredici hükme bağlamıştır. Aynı maddede bu durumun istisnalarını bildirmiştir. Diğer bir istisna ise HMK m. 141' dir. Burada güdülen amaç, uyuşmazlık konularının ve uyuşmazlık konularına ilişkin delillerin tahkikata geçilmeden önce belirlenmesidir. Kanun koyucu, tahkikata geçmeden önce delillerin tespit edilmesi gerekliliğini HMK m. 140/5' de tarafların dilekçelerinde gösterdikleri; ancak sunmadıkları delillerini sunmaları için verilen iki haftalık kesin süre içerisinde sunmamaları halinde o delile dayanmaktan vazgeçmişs sayılacaklarına ilişkin yaptırım ile de açıkça ortaya koymuştur.

HMK m. 145 ' te tarafların belirtilen sürelerden sonra delil gösteremeyeceklerinin kesin bir dil ile ifade edilmesi karşısında; yasal süresi içerisinde cevap dilekçesi vermeyen davalının, sonradan delil listesi sunması, istisnai haller saklı kalmak kaydıyla, mümkün değildir ${ }^{[60]}$. HMK 145. maddenin gerekçesinde de; "Uygulamada, davaların uzamasının temel sebeplerinden birinin de gereksiz yere yeni delil sunulması ve bu konuda taraflara verilen sürelere uyulmaması olduğunun bilindiği, maddenin ilk fikrasıyla, Kanunda belirtilen sürelerden sonra, davada yeni delil sunulmasının yasak olduğunun kural olarak benimsendiği, fakat iki istisnanın kabul edildiği, bunun için; yeni delil sunulması talebinin yargılamayı geciktirme amacı taşımaması veya delilin süresinde sunulmamasının

davaya süresi içerisinde cevap vermeyen davalının hiçbir şekilde delil sunma hakkının olmadığı görüşündeyim.

[60] Yılmaz, Ramazan: HMK Uyarınca Tüm Delillerin Dava veya Cevap Dilekçesinde Gösterilmesi ve Eklenmesinin Zorunlu Olup Olmadığı, İstanbul Barosu Dergisi, C:86, S:2012/5, (s.262-265), s. 264, 265; Erdönmez, Güray: Hukuk Muhakemeleri Kanunu Bakımından Delillerin İbrazı, Medeni Usul ve İcra İflas Hukukçuları Toplantısı X, 1-2 Ekim 2012 İzmir, (s.348-376), s. 363, 364; Pekcanıtez/Atalay/Özekes, s. 192; Erdönmez, Güray: Hukuk Muhakemeleri Kanununa Göre Delillerin Gösterilmesi ve İbrazı, İstanbul Barosu Dergisi, Eylül-Ekim 2013, C: LXXXVII, S:5, (s. 15-53), s. 32; Bolayır, Nur: Hukuk Yargılamasında Delillerin Toplanmasında Tarafların ve Hâkimin Rolü, İstanbul 2014, s. 234; Pekcanıtez/Özekes/Akkan/Taş-Korkmaz, s. 1206. 
ilgili tarafın kusuru dışında bir sebebe dayanması halinde, hâkimin gerekçesini de belirtmek şartıyla, yeni delil sunulmasına izin verebileceği, bu şekilde delil sunma kuralına istisna getirilmesinin hukuki dinlenme hakkının tabii bir sonucu olduğu" belirtilmiştir.

Cevap dilekçesi vermeyen davalı, davacının dava dilekçesinde bildirdiği vakıaların dışında yeni bir vakıa da sunamayacaktır ${ }^{[61]}$. Bu durumda davacı, iddia ettiği vakıaları ancak dava dilekçesinde sunmuş olduğu delillerle ispatlayabilecektir. Davacının ileri sürmüș olduğu vakıalar ve deliller, karşı bir iddia ileri sürülmeden davalıca inkâr edilmiş kabul edilecektir. Öyleyse, davacının iddiasını ispatlaması, davalının süresi içerisinde cevap dilekçesi vermesi durumuna göre daha kolay olacaktır.

\section{B- Cevap Dilekçesi Verilmemesinin Davalı Açısından Sonuçları}

Davalının, aleyhinde açılmış olan davaya süresi içerisinde cevap vermemesi durumunda oluşacak sonuçlar HMK m. 128' de düzenlenmiştir. HMK m. 128 hükmü gereğince; "Süresi içinde cevap dilekçesi vermemiş olan davalı, davacının dava dilekçesinde ileri sürdügü vakıaların tamamını inkâr etmiş sayılır.". Maddenin lafzı incelendiğinde de görüleceği üzere madde, sadece davalı açısından doğan sonuçları düzenlemiştir. Madde, süresi içerisinde cevap dilekçesi vermeyen davalının, davacının ileri sürmüş olduğu vakıaları inkâr etmiş sayılacağını bildirmektedir ${ }^{[62]}$.

[61] Ankara Bölge Adliye Mahkemesi 2. HD., 09.02.2017, E. 2017/68, K. 2017/148; “Dosya incelendiğinde davalının, dava dilekçesinin tebliğinden itibaren iki hafta süre içerisinde cevap dilekçesi ibraz etmemiştir. (HMK md. 127/1). Süresi içerisinde cevap dilekçesi vermemiş olan davalı erkek, davacı kadının dava dilekçesinde ileri sürdügü vakıaların tamamını inkâr etmiş sayılır (HMK md. 128/1). Davalı erkeğin yasal süresinden sonra verdiği cevap dilekçesinde yer alan vakıalar davacı kadına kusur olarak yüklenemeyeceğinden boşanmaya sebep olan olaylarda davalı erkek tam kusurludur. Mahkemece tarafların eşit kusurlu kabul edilmesi doğru görülmemiştir." (sinerjimevzuat.com). Eroğlu’na göre; "Dilekçelerinin teatisinden sonra ortaya çıkan yeni bir vakıanın ileri sürülmesi de iddianın veya savunmanın değiştirilmesi veya genişletilmesi yasağı kapsamındadır. Ancak bu vakıa iddianın veya savunmanın değiştirilmesi veya genişletilmesi yasağının uygulanmadığı dönemde ileri sürülen iddia veya vakıalarla bağlantılı veya onları tamamlayıcı mahiyette ise yasak kapsamında kabul edilmez. Yeni iddiaların veya bu kapsamdaki vakıaların ortaya çımmasından sonraki ilk oturumda ileri sürülmesi usul ekonomisi açısından yerinde bir uygulama olur." Eroğlu, s. 50.

[62] Kiraz, s. 147; Sungurtekin-Özkan, s. 196; Baumbach /Lauterbach/Albers/ Hartmann, s. 703; Kuru/Arslan/Yılmaz, s. 334; Pekcanıtez/Atalay/Özekes, s. 334; Karahacioğlu/ Parlar, s. 126; Kuru, s. 181; Postacıoğlu/Altay, s. 470, 471; Görgün, s. 220; Ulukap1, s. 268; Umar, s. 411, 412; Kuru, İstinaf, s. 260; Tanriver, s. 659; Arslan/Yılmaz/ 
HMK m. 128 incelendiğinde de görüleceği üzere kanunda yer alan bu düzenleme, Türk hukuk sisteminde susmanın diğer birçok hukuk sisteminden farklı olarak ikrar olarak kabul edilmediği, aksine susmanın inkâr olarak kabul edildiği ve ispat yükünün hangi tarafın üzerinde olduğu açısından da taraflar arasında bir farklılık oluşturmadığı sonucunu doğurmaktadır ${ }^{[63]}$.

Alman hukuk sisteminde ZPO m. 277/3 uyarınca davaya cevap süresi kural olarak iki haftadır ${ }^{[64]}$. Cevap dilekçesinin geç sunulması ZPO m. 296' da düzenlenmiştir ${ }^{[65]}$. Söz konusu maddeye göre; cevap süresi olan iki haftalık sürenin kaçırılması halinde, geç sunulan cevap dilekçesinin kabul edilmesi hususunda mahkemenin takdir hakkı mevcuttur. Mahkeme, takdir hakkını serbestçe kullanarak iki halde süresi geçtikten sonra verilen cevap dilekçesini kabul edebilir. Bunlardan ilki, mahkemenin geç verilen cevap dilekçesinin yargılamanın uzamasına sebebiyet vermemesi noktasında ikna olması; diğeri ise süreyi kaçıran tarafın bu husustaki haklılığı bakımından yeteri kadar meşru gerekçeler ortaya koyabilmesi ve mahkemeyi ikna edebilmesidir. Cevap dilekçesi verilmemesi halinde davacı, ZPO m. 331/3 fikrasının birinci cümlesi uyarınca giyap hükmü verilmesini mahkemeden talep edebilir ${ }^{[66]}$. ZPO m. 331/3 fik-

Taşpınar-Ayvaz, s. 338; Görgün/Börü/Toraman/Kodakoğlu, s. 322; Pekcanıtez/ Özekes/Akkan/Taş-Korkmaz, s. 1203.

[63] Berkin, Necmettin M.: Medeni Usul Hukuku Esasları, İstanbul 1969, s. 136, 137; Selçuk, s. 841; Yilmaz, Orhan: Esasa Verilebilecek Cevaplar, TBBD, 1990/3, (s.401-414), s. 404; Kuru, Baki: Hukuk Muhakemeleri Usulü El Kitabı, İstanbul 1995, s. 388; Üstündăg, s. 510; Kiraz, s. 147; Kuru, Şerh, C:II, s. 1847; Okur, Mustafa: Medeni Usul Hukukunda Davaya Cevap, Y.Lisans Tezi, Ankara 2002, s. 132; Sungurtekin-Özkan, s. 196; Kuru/ Arslan/Yılmaz, s. 334; Pekcanıtez/Atalay/Özekes, s. 334; Karahacioğlu/Parlar, s. 126; Kuru, s. 181; Postacığlu/Altay, s. 470, 471; Görgün, s. 220; Ulukapı, s. 268; Umar, s. 411, 412; Kuru, İstinaf, s. 260; Tanrıver, s. 659; Arslan/Yılmaz/Taşpınar-Ayvaz, s. 338; Görgün/Börü/Toraman/Kodakoğlu, s. 322; Pekcanıtez/Özekes/Akkan/Taş-Korkmaz, s. 1203; Y.22.HD., 20.06.2017, E. 2017/33948, K.. 2017/14899 ; "Davalı tarafça davaya cevap dilekçesi sunulmamış ise de, 6100 Sayılı Hukuk Muhakemeleri Kanunu’nun 128. Maddesinde açıkça belirttiği üzere, süresi içinde cevap dilekçesi vermemiş olan davalı, davacının dava dilekçesinde ileri sürdüğü vakıaların tamamını inkar etmiş sayılır. 6100 Sayılı Kanun'un 33. Maddesi uyarınca da, hâkim Türk hukukunu resen uygulamakla yükümlüdür. Dolayısıyla davaya cevap dilekçesinin sunulmamış olması davaya konu uyuşmazlığın çözümünde ilgili hukuk kurallarının nazara alınmasına engel değildir." (sinerjimevzuat.com-Erişim tarihi:18.01.2018).

[64] Baumbach, Adolf/Lauterbach, Wolfgang/Albers, Jan/Hartmann, Peter: Zivilprozessordnung, München 2014, s. 1133, 1134; Pohlman, Petra: Zivilprozessrecht, Mühchen 2011, s. 220.

[65] Baumbach/Lauterbach/Albers/Hartmann, s. 1290, 1291; Pohlman, s. 224.

[66] Baumbach/Lauterbach/Albers/Hartmann, s. 1278, 1279. 
rasının ikinci cümlesi uyarınca ve Alman mahkemeler uygulamasında gıyap hükmü verilmesi ile ilgili dilekçe, usul ekonomisi sebebi ile dava dilekçesine eklenmelidir. Gıyap kararı üzerine yargılama bir bakıma davacı açısından devam edecek, davalı ileri sürebileceği savunma sebeplerinden yoksun bırakılacaktır.

Alman hukuk sisteminde genel olarak iddianın veya savunmanın değiştirilmesi veya genişletilmesi yasağı bulunmamaktadır. Ancak usulü itirazların, esasın incelenmesine başlanmadan önce ZPO m. 274' e göre bildirilmesi gerekmektedir. Usulü itirazların, yargılamanın ilerleyen safhalarında ileri sürülmeleri sert müeyyidelere bağlanmıştır ${ }^{[67]}$. ZPO m. 278/1 hükmü gereğince taraflar, vakıaları ve delillerini yargılamanın sonuna kadar serbestçe sunabilirler ${ }^{[68]}$. Ancak, taraflar, vakıa ve delillerini ağır ihmallerinden dolayı veya yargılamayı sürüncemede bırakmak maksadı ile geç ileri sürmüşlerse; mahkeme ZPO m. 279/1 hükmü gereğince vakıa ve delilleri yargılamaya dâhil etmeyebilir ${ }^{[69]}$.

Alman hukuk sisteminde, normal dava prosedürü haricinde bir de ihbarlı davetiye sistemi olan "Mahnverfahren" müessesesi bulunmaktadır. "Mahnverfahren" müessesesinde, özellikle para alacaklarında, mahkeme karşı tarafa bir ihbarlı davetiye göndermektedir. Karşı taraf eğer ihbarlı davetiyeye bir cevap veya karşılık verirse, mahkeme yargılamaya başlamakta ve davacının iddialarını ispat açısından incelemektedir. Ancak karşı taraf davetiyeye herhangi bir karşılık vermezse davacı, mahkemeden alacağı kararla, karşı tarafa ilamlı icra emri gönderebilmektedir ${ }^{[70]}$. Alman hukukundaki "Mahnverfahren" müessesesi, sadece bu uygulamada susmanın ikrar olarak kabul edildiği sonucuna ulaşmamıza sebep olmaktadır. Türk hukuk sisteminde susmanın inkâr olarak kabul edilmesi gerek Anglo-Amerikan hukuk sisteminden gerekse de Alman hukuk sisteminden bu yönleri ile ayrılmaktadır.

Süresi içerisinde davaya cevap vermeyen davalı gerek ön inceleme aşamasında gerekse de tahkikat aşamasında inkâr kapsamında beyanda bulunabilir. İnkâr, kapsamında olmayan beyanlar ise savunmanın değiştirilmesi veya genişletilmesi sayılacaktır. Davaya cevap vermeyen davalı, vermiş olduğu beyan dilekçesinde davaya yönelik yeni vakıa ileri süremez. İtiraz ve def'i de bildiremez. Ancak davacının bildirdiği vakıalara karşı cevap mahiyetinde beyanda bulunabilir. Davalının bu şekilde mahkemeye sunmuş olduğu beyanı, hâkimin takdiri açısından önemlidir. Yoksa davalının bu beyan dilekçesiyle yeni vakıalar ileri

[67] Jauernig/Hess, s. 137, 138; Baumbach/Lauterbach/Albers/Hartmann, s. 1125, 1126.

[68] Jauernig/Hess, s. 4; Baumbach/Lauterbach/Albers/Hartmann, s. 1136.

[69] Baumbach/Lauterbach/Albers/Hartmann, s. 1156.

[70] Pohlman, s. 343. 
sürmesi halinde, bu vakıalar araştırılamaz. Davalı, bu beyan dilekçeleriyle herhangi bir delil de sunamaz.

Davalının cevap dilekçesi ile ileri sürmediği savunma sebebi eğer hâkim tarafından kendiliğinden göz önüne alınması gereken bir sebepse, bu sebebin ileri sürülmesi yasak kapsamında değildir ${ }^{[71]}$. Örneğin, davalı cevap dilekçesi vermemiş olmasına rağmen yargılama esnasında takas hakkını kullandığını iddia edebilir. Takas, borcu sona erdiren sebeplerdendir ve borcun sona ermesi bir itirazdır ${ }^{[72]}$. Bu nedenle hâkim bu hususu kendiliğinden göz önünde bulunduracaktır.

Yargıtay, ödeme iddiasını da cevap dilekçesi vermeyerek davayı inkâr etmiş kabul edilen davalının inkârı kapsamında değerlendirmiş ve bu nedenle ödemeye ilişkin belge ve makbuzların davalı tarafından ileri sürülebilmesine imkân sağlamıştır ${ }^{[73]}$. Doktrinde ödeme iddiasının inkâr kapsamında olduğunu kabul

[71] Y.4.HD., 22.01.1981, E. 1980/13429, K. 1981/354; "Takas karşllık dava olarak ileri sürülebileceği gibi def'i olarak da ileri sürülebilir ve def'i olarak ileri sürüldügü hallerde diğer savunmaların tabi bulunduğu yasa hükümlerine tabi olur. Davacının alacak iddiasının ancak bir kısmı ya da tamamını ret ettirmeyi amaç tutup kendi yararına ayrıca bir alacak hükmedilmesini istemeyen bir davalının mutlaka karşılık dava açması söz konusu olamaz. Çünkü Esas davadan daha az veya ona eşit miktarda karşılık zararı veya alacağı bulunan davalının bunu ileri sürebilmesi için karşılık dava açmaya zorlanması usule aykıı düşer. (Baki Kuru-H.U.M.K. 3. Baskı-Ankara 1974 Sayfa 596 ve devamı) Bu sebeple mahkemece yapılacak iş bu trafik olayı davalının da aracında meydana gelen hasar tespit edilerek ve kusuru oranı da göz önünde bulundurularak tespit edilecek alacağının, davacının alacağından düşülmesi suretiyle sonucuna göre bir karar vermekten ibarettir." (www. sinerjimevzuat.com.tr-Erişim tarihi: 20.03.2018); Aynı yönde diğer kararlar için bakınız; YHGK., 15.05.1987, E. 1986/14-705, K. 1987/390; YHGK, 12.04.1967, E. 1966/280, K. 1967/195 (Topuz, Gökçen/Topuz, Seçkin: Takasın Davada ileri Sürülmesi, AÜHFD, Y1l: 2008, C:57, S: 3, s. 724).

[72] Üstündăg, Saim: Borçlar Hukuku Hükümlerine Göre Takas ve Davada Kullanılmasının Arz Ettiği Özellikler, İstanbul Üniversitesi Hukuk Fakültesi Mecmuası 1959, C.XXV, S:1-4, s. 215; Topuz/Topuz, s. 721; Görgün, s. 230; Kuru, "Borcu söndüren sebeplerinde iddia ve savunmanın değiştirilmesi ve genişletilmesi yasağına tabi olduğunu ve değiştirme ve genişletme süresi içerisinde mahkemeye sunulmazsa mahkemece re’sen göz önüne alınamayacağı,” görüşündedir. (Kuru, Şerh, C:II, s. 1814.).

[73] Y.H.G.K., 12.02.1986, E. 1984/6-717, K. 1986/110; "Davalı süresinde cevap dilekçesi vermemekle davayı inkar etmiş sayılır. Davayı inkarın içerisinde borcun ödendiği iddiası da vardır. Bu sebeple, cevap vermemek suretiyle davayı inkar etmiş sayılan davalı sonradan savunmanın genişletilmesi yasağı ile karşılaşmaksızın dava konusu borcun ödendiğini ispat için makbuz ibraz edebilir. Ancak esas hakkında karar verilmekle hakim işten el çekmiş olduğundan bundan sonra, temyiz incelemesi sırasında borcun ödendiğini ispat icin makbuz ibraz edilemez." (www.sinerjimevzuat.com.tr-Erişim Tarihi:20.03.2018);

Alangoya/ Yıldırım/ Deren-Yıldırım, s. 254. 
eden yazarlar mevcut olduğu gibi; karşı görüşte olan yazarlar da vardır ${ }^{[74]}$. Cevap dilekçesinin verilmemesi halinde davalının davanın tümünü inkâr etmiş sayılacağı göz önünde bulundurulduğunda, davacının ödenmeme iddiasına karşılık davalının inkâr kapsamında ödemeye ilişkin makbuz sunabileceği kanaatindeyim. Aksi katı şekilcilik teşkil eder ve yargılamanın yegane amacı maddi mutlak gerçek, katı şekilcilik uğruna feda edilir.

Türk hukuk sisteminde teksif ilkesi kabul edilmiştir. Teksif ilkesi gereğince, bütün iddia ve savunma sebepleri ancak belirli bir usul kesitine kadar ileri sürülebilir. Bu usul kesitinden sonra ileri sürülen iddia veya vakıalar mahkemece kabul edilmemektedir ${ }^{[75]}$. Davaya cevap dilekçesi vermeyen davalının, sonrasında yeni delil ve vakıa ileri sürememesi bu nedenden kaynaklanmaktadır. Ancak taraflarca getirilme ilkesinin istisnalarından biri kendiliğinden araştırma ilkesidir. Kendiliğinden araştırma ilkesi, bu ilkenin uygulandığı davaların kamu düzenini ilgilendirmesi sebebi ile kabul edilmiştir. Kendiliğinden araştırma ilkesinin uygulandığı davalar, tarafların üzerinde serbestçe tasarruf edemeyecekleri davalardır ${ }^{[76]}$. Örneğin; babalık, nüfus kaydının düzeltilmesi, nesebin reddi gibi davalarda davanın konusu üzerinde taraflar serbestçe tasarruf edememektedir. Kendiliğinden araştırma ilkesinin uygulandığı davalarda hâkim, tarafların ileri sürdüğü vakıa ve delillerle bağlı değildir. Kendiliğinden araştırma ilkesinin uygulandığı davalarda, HMK m. 141' de düzenlenen iddianın veya

[74] Postacıŏlu, İlhan: Davanın ve Kaziyei Muhkemenin Unsuru Olarak Hukuki Sebep, Dr. A. Recai Seçkin'e Armağan, Ankara 1974, (s.497-527), s.519;Y.4.HD., 20.12.1974, E. 1973/6155, K. 1974/17127; "Davalı süresinde cevap lahiyası vermemiş ve davayı inkâr etmiştir. Bu inkârın içinde borcun söndüğü iddiası da var farzedilir." (www.kararara.comErişim Tarihi:20.03.2018)Karşı görüşte olan Üstündağ, ödemeye ilişkin itirazın inkar kapsamında değerlendirilemeyeceğini ileri sürmüştür ( Üstündağ, Yargıtay'ın vermiş olduğu "inkâr, uyuşmazlık konusu olayların ileri sürüldüğü üzere değil, başka şekilde gerçekleştiğini bildirme” (4.HD., 17.12.1965 T., 964/10175-7469) şeklindeki kararında, ödeme itirazının inkâr savunması içerisinde ifade edilemeyeceği eleştirisini yapmıştır. (Üstündağ, s. 508-509).

[75] Postacioğlu, s. 252; Bilge, s. 264; Üstündă̆, s. 253; Alangoya, s. 4; Kuru, Şerh, C:IV, s. 3966,3967; Olgun, Sevinç: Islah Yolu İle Düzeltilemeyecek İşlemler, Terazi Hukuk Dergisi, S:16, Y:2, Ankara, Aralık 2007, (s.43-53), s. 43; Pekcanıtez/Atalay/Özekes, s. 368; Sungurtekin-Özkan, s. 101, 102; Karslı, s. 268; Kuru/Arslan/Yılmaz, s. 554; Pekcanıtez/Atalay/Özekes, s. 368; Görgün, s. 240; Ulukapı, s. 128; Postacıŏlu/ Altay, s. 169; Ulukapı, s. 128; Arslan/Yılmaz/Taşpınar-Ayvaz, s. 156; Tanrıver, s. 362; Görgün/Börü// Toraman/Kodakoğlu, s. 355.

[76] Bilge, s. 260; Üstündağ, s. 250; Sungurtekin-Özkan, s. 98; Pekcanıtez/Atalay/Özekes, s. 366, 367; Karslı, s. 261; Görgün, s. 240; Ulukapı, s. 119; Tanrıver, s. 361; Arslan/ Yılmaz/Taşpınar-Ayvaz, s. 153, 154; Görgün/Börü/Toraman/Kodakoğlu, s. 354; Pekcanıtez/Özekes/Akkan/Taş-Korkmaz, s. 806. 
savunmanın değiştirilmesi veya genişletilmesi yasağı da uygulanmaz ${ }^{[7]]}$. Bu nedenle kendiliğinden araştırma ilkesinin uygulandığı davalarda, davalının süresi içerisinde cevap dilekçesi vermemesinin bir önemi yoktur. Davalı, davanın her aşamasında mahkemeye yeni delil sunabilir, daha önce sunmadığı itiraz ve def' ilerini ileri sürebilir.

Mahkemece ön inceleme duruşması için gün verilerek, davalıya delillerini ibraz etmesi için usulüne uygun olarak ihtar yapılmısssa; davalının ön inceleme duruşmasından önce cevap dilekçesi vermesi ve delil listesini sunması halinde, davalı süresi içerisinde cevap dilekçesi vermemiş olsa dahi inkâr kapsamında bildirmiş olduğu tanıkların dinlenmesi gerektiği kanaatindeyim. Çünkü uyuşmazlık ön inceleme duruşması ile tespit edilecektir ve taraflardan uyuşmazlık konusu tespit edilmeden tanık listesi sunmasının beklenmesi mümkün değildir. Ayrıca hukuki dinlenilme hakkı gereği de davalıya HMK m. 27 hükmü gereğince tanık dinletme imkânının tanınması gerekmektedir. Yargıtay’ ın da bu yönde kararları mevcuttur ${ }^{[78]}$.

Süresi içerisinde cevap dilekçesi vermeyen davalının, def' i ve itirazlarını ıslah yoluyla ileri sürebilip süremeyeceği gerek doktrinde tartışma konusu olmuş gerekse de Yargıtay daireleri bu hususta çelişik kararlar vermiştir. Süresinde

[77] Bilge, s. 260; Üstündağ, Saim: İddia ve Müdafaanın Değiştirilmesi Yasağı, İÜHFY, No:266, İstanbul 1967, s. 161; Üstündağ, s. 250; Kaya, Cemil/Akcan, Recep: Medeni ve İdari Yargıda İddia ve Savunmanın Genişletilmesi veya Değiştirilmesi Yasağı, İÜHFM, C:LXVII, S. 1-2, (s.123-142), İstanbul 2009, s. 126; Kuru, Şerh, C:II, s. 1839; Yılmaz, Ejder: Hukuk Muhakemeleri Şerhi, Ankara 2012, s. 862; Mustafa Ateş: Hukuk Muhakemeleri Kanunu, Yargitay İlke Kararları, C:1-2, Ankara 2013, s. 787, 788; Sungurtekin-Özkan, s. 98; Pekcanıtez/Atalay/Özekes, s. 366, 367; Karslı, s. 261; Görgün, s. 240; Ulukapı, s. 119; Tanriver, s. 361; Arslan/Yılmaz/Taşpınar-Ayvaz, s. 153, 154; Görgün/Börü/ Toraman/Kodakoğlu, s. 354, 322; Eroğlu, s. 44.

[78] Y.2.HD., 11.12.2013, E. 2013/16048, K. 2013/29319; "Davac1 ön inceleme duruşmasından önce delil listesini ibraz etmiş, davalı ise cevap süresi geçtikten sonra cevap ve delil listesi sunmuştur, ön inceleme duruşması yapılmış ve anlaşamadıkları hususlar tespit edilmiştir. Davalı tarafından bildirilen tanıklar, süresinde bildirilmediği gerekçesiyle dinlenmesi talebinin reddine karar verilmiştir. Ön inceleme duruşması yapılmadan, tensiple taraflara, dilekçelerinde göstermiş oldukları ve belge niteliğindeki delilleri sunmaları veya bulundukları yerlerle ilgili açıklamada bulunmaları için süre verilmesi bu anlamda sonuç doğurmaz. Delil, çekişmeli vakıaların ispatı için gösterilir. Ön inceleme duruşması yapılmadan, tarafların üzerinde anlaştıkları ve anlaşamadıkları hususlar belirlenmeden, tarafların tanık listesi vermeleri de beklenemez. Süresinde cevap ve delil bildirmeyen davalının, davacının dava dilekçesinde dayandığı vakıaları inkar etmiş olacağına göre, ön inceleme duruşmasından önce bildirdiği tanıkların da bu doğrultuda dinlenmesi gerekir."; Y.2.HD., 12.06.2013, E. 2013/4273, K. 2013/16392 (www.kararara. com-Erişim Tarihi: 20.03.2018). 
cevap dilekçesi vermeyen davalının eylemi olumsuz bir davranıştır. Yılmaz' ın görüşüne göre, davalı bu durumda cevap dilekçesini ıslah edemez. Yılmaz’ a göre davaya cevap vermemek usulü bir işlem değildir ${ }^{[79]}$. Aynı görüşü savunan başka yazarlar da mevcuttur ${ }^{[80]}$. Meriç ise, cevap dilekçesi vermemenin de bir usul işlemi olduğunu ve davalı tarafın kısmi ıslah yoluyla zamanaşımı def' ini ileri sürebileceğini savunmaktadır ${ }^{[81]}$. Yasal süresi içerisinde cevap dilekçesi sunmayan davalının ıslah yolu ile zamanaşımı def' inde bulunabileceği görüşünde olan yazarlara göre; katı teksif ilkesinin bir istisnası olan ıslahtan, davalının cevap dilekçesi vermemiş olması sebebi ile yoksun bırakılması halinde; katı şekilcilik, maddi gerçekliğe tercih edilecek ve haksız sonuçlar meydana gelecektir. Karafakih ise, bu konuda daha da ileri bir görüşle zamanaşımı def'inin ilk itiraz olmaması sebebiyle yargılamanın her aşamasında ileri sürülebileceğini, ancak geç ileri sürülmesinin kötü niyetle olduğu tespit edilmesi halinde hâkim tarafından nazara alınmaması gerektiğini ileri sürmüştür ${ }^{[82]}$. Üstündağ ise, Karafakih' in görüşüne karşı bir cevap mahiyetinde olan çalışmasında ${ }^{[83]}$, yasal süresi içerisinde cevap dilekçesi vermemiş olan davalının, ıslah yolu ile zamanaşımı def' ini ileri süremeyeceğini, yapılmamış bir usul işleminin ıslah edilmesinin mümkün olmadığını savunmuştur ${ }^{[84]}$. Üstündağ, aksi halde teksif ilkesine aykırı durumların meydana geleceğini ileri sürmüştür.

YHGK, cevap dilekçesi vermiş; ancak vermiş olduğu cevap dilekçesinde zamanaşımı def' ini ileri sürmeyi unutan davalının ıslah yolu ile zamanaşımı def' ini ileri sürebileceği yönünde görüş bildirmiştir ${ }^{[85]}$. Burada dikkat edilmesi

[79] Yılmaz, Ejder: Medeni Yargılama Hukukunda Islah, 6100 sayılı HMK' na göre Değiştirilmiş, Ankara 2013, s. 130.

[80] Selçuk, s. 841, 842; Üstündağ, s. 510, 511;

[81] Meriç, Nedim: Zamanaşımı Def'ine İlişkin Bazı Medeni Yargılama Hukuku Meseleleri (Haluk Konuralp Anısına Armağan, C.1, Ankara 2009), (s.679-704), s. 693, 694. Aynı görüşte olan yazarlar; Ansay, Sabri Şakir: Islah, AÜHFD 1950, C:7, S:1-2, (s.122-129), s. 123; Berkin, s.145; Pekcanıtez, Hakan/Akyazılı, Erdem: Islaha İlişkin Bazı Yargıtay Kararlarının İncelenmesi, Uğur Alacakaptan’a Armağan, İstanbul 2008, (s.553-559), s. 554; Alangoya/Yıldırım/Deren-Yıldırım, s. 264; Postacıoğlu/Altay, s. 543; Kuru, İstinaf, s. 262, 263; Eroğlu, s. 82.

[82] Karafakih, İsmail Hakkı: Cevap Layihası Vermemiş olan Davalı Müruruzaman Dermeyan Hakkını İskat Etmiş Midir?, İstanbul Barosu Dergisi, 1962/1,2,3, (s. 13-19), s. 19.

[83] Üstündăg, Saim: Süresinde Cevap Lahiyası Vermemenin Müeyyidesi Vardır, İstanbul Barosu Dergisi, 1966/4,5,6, (s.22-36), s. 35.

[84] Aynı görüşte bir başka yazar; Postacıŏlu, s. 455-456.

[85] YHGK., 06.04.2011, E. 2010/ 9-629, K. 2011 / 70; "Zamanaşımı maddi hukuktan kaynaklanan bir def'i ve savunma aracı olup, davacının başında, süresinde verilecek 
gereken husus cevap dilekçesi verilmiş ve cevap dilekçesinde zamanaşımı def' inin ileri sürülmesinin unutulmuş olmasıdır. YHGK' nın da kararında belirttiği üzere ıslah yolu ile zamanaşımı def' inin ileri sürülmesi mümkündür. Bu aşamadan sonra incelenmesi gereken husus cevap dilekçesinin verilmemiş olması halidir. Davanın takip edilmemesi sebebi ile dosyanın işlemden kaldırılması nasıl olumsuz bir usul işlemi ise, davaya hiç cevap verilmemesi de aynı şekilde olumsuz bir usul işlemidir. Usul işlemleri olumlu olabileceği gibi, olumsuz da olabilir ${ }^{[8]}$. Bu nedenle davaya hiç cevap vermeyen davalı, savunma dilekçesinin tamamını ıslah ederek zamanaşımı def' inde bulunabilmelidir. Çünkü davalının, "davacının davasını ya da iddialarını kabul etmiyorum" şeklinde vereceği bir dilekçe ile davaya hiç cevap vermemesi arasında usul hukuku açısından hiçbir fark yoktur.

Yaşanan tartışma, cevap dilekçesi vermeyen davalının, daha sonra ıslah yolu ile zamanaşımı def' ini ileri sürülebilip süremeyeceği konusunda dar kapsamda yaşanmaktadır. Ancak kasıtlı veya ihmali olarak cevap dilekçesi verme süresini geçirmiş olan davalıya, adil yargılanma ve hukuki dinlenilme hakkı kapsamında, hakkaniyet gereği ıslah hakkının tanınması gerekmektedir ${ }^{[87]}$. Öyleyse; davaya

cevap dilekçesinde (veya sözlü yargılama usulünde ilk oturumda esasa girişmeden önce) ileri sürülmelidir. Zamanaşımı def'inin, yukarıda belirtilen aşama geçildikten sonra ileri sürülmesi, savunmanın genişletilmesi ve değiştirilmesi anlamına gelir. Bu durum ise, karşı tarafın izni (açık veya zımni) olmaksızın yada ıslah yoluna gidilmezse geçerli değildir. Zamanaşımı def'i, unutma veya benzeri nedenlerle, davanın başında ileri sürülmemiş olabilir. Daha sonra bu durumun farkına varılırsa, ıslah yoluyla ileri sürülebilmesi gerekir.”. Aynı yönde bakınız; YHGK., 19.02.1958, E:4-23, K:16; 13.02.1963, E:4-51, K:19 sayılı kararları (www.sinerjimevzuat.com.tr-Erişim tarihi: 09.05.2018).

[86] Karslı, Abdurrahim: Medeni Usul Hukukunda Usuli İşlemler, İstanbul 2001, s. 172; Yılmaz, Islah, s. 137; Eroğlu, s. 81, 82; Pekcanıtez/Özekes/Akkan/Taş-Korkmaz, s. 436.

[87] Y.23.HD., 23.02.2017, E. 2017/99, K. 2017/567; "Mahkemece, hukuki niteliği itibariyle maddi hukuktan kaynaklanan zamanaşımı def'inin ilk itirazlardan olmadığı, süresinden sonra cevap dilekçesi verilmesinin ya da hiç cevap dilekçesi verilmemesinin ıslahen zamanaşımı def'i hakkını ortadan kaldırmayacağı, ıslah yolu ile zamanaşımı def'inin ileri sürülebilmesi için süresinde cevap dilekçesi verilmiş olup olmadığı gibi ayrım yapılmasının ıslah kurumunun amacına ve eşitlik ilkesine aykııı olduğu sonucuna ulaşılmıştır." (sinerjimevzuat.com-Erişim tarihi:18.01.2018); Bu görüşte olan yazarlar; Yılmaz, Ejder: Dünden Bugüne Hukuk Usulü Muhakemeleri Kanunumuz (Cumhuriyetin Kuruluşundan Bugüne Türk Hukukunun Seksen Yıllık Gelişimi, Sempozyum, Ankara, 2003, (Yilmaz, Sempozyum), s. 243-278; Pekcanıtez/Atalay/Özekes, s. 618; SungurtekinÖzkan, s. 232; Umar, s. 516; ; Tutumlu, Islah, s. 39, 40; Eroğlu, s. 82; Kuru, İstinaf, s. 592.; Pekcanıtez/Özekes/Akkan/Taş-Korkmaz, s. 1534; Aksi yönde bir Yargıtay kararına göre; YHGK, 07.06.2017, E. 2016/1212, K. 2017/1078; “Davalının süresinden sonra verdiği cevap dilekçesini slah ederek zamanaşımı def' inde bulunabileceğini kabul 
süresi içerisinde cevap dilekçesi vermeyen davalının, ıslah yoluyla yahut karşı tarafın açık muvafakati ${ }^{[88]}$ ile tahkikat aşamasında cevap dilekçesi verebileceği ve bu yolla yeni vakıalar ve deliller sunabileceği görüşündeyim.

Önemle belirtmek gerekir ki HMK m. 176' nın madde gerekçesinde ${ }^{[89]}$, davalının cevap dilekçesini ıslah etmek sureti ile zamanaşımı def' ini ileri sürebileceğinin mümkün olduğu açıklığa kavuşturulmuştur. Bu kapsamda, zamanaşımı def' inin cevap dilekçesinin sslahı yoluyla ileri sürülebileceği sonucuna ulaşılmıştır. Bu uygulamanın, madde gerekçesinde geçiyor olması, zamanaşımı def'inin cevap dilekçesinin ıslahı yoluyla ileri sürülebileceği sonucuna yorum yoluyla ulaşılmasına sebep olsa da yine de bu konudaki tartışmaları ve yargı kararlarındaki farklılıkları büyük ölçüde ortadan kaldırmıştır.

YHGK, yeni tarihli bir kararında süresi içerisinde cevap dilekçesi sunmayan davalının ıslah yolu ile zamanaşımı def' i ileri süremeyeceği yönünde karar vermiştir. YHGK ${ }^{[90]}$, sslahın konusunun usul işlemleri olduğu, taraflardan

etmek ıslah ile kaçırılmış olan sürenin geri getirilmesi, daha doğrusu ıslah ile davaya cevap verilmesi sonucunu doğuracaktır. Oysa ki kanun ile belirlenen süreler kesin olup, ıslah kaçırılmış olan süreleri geri getiren bir yol değildir." (sinerjimevzuat.com-Erişim tarihi:09.05.2018).

[88] Y.9.HD., 05.10.2017, E.2017/24801, K.2017/15006; “Cevap dilekçesinde zamanaşımı def'i ileri sürülmemiş ya da süresi içinde cevap dilekçesi verilmemişse ilerleyen aşamalarda 6100 Sayılı Hukuk Muhakemeleri Kanunu'nun 141/2 maddesi uyarınca zamanaşımı def'i davacının açık muvafakati ile yapılabilir." (sinerjimevzuat.com-Erişim tarihi:09.05.2018).

[89] "Islah yolu ile davanın geciktirilmesi ve sürüncemede bırakılması mümkün olduğundan, ikinci fikra ile tarafların ıslah yoluna bir defa başvurabileceklerine ilişkin sınırlama bu Tasarıda da kabul edilmiştir. Uygulamada, zamanaşımının ıslah yolu ile ileri sürülüp sürülemeyeceğine dair bazı tereddütler var ise de zamanaşımı ilk itiraz olmayıp, slah yolu ile de ileri sürülebileceğinde tereddüt etmemek gerekir." 16.04.2008, Dönem 23, Yasama Y1lı:3, Hukuk Muhakemeleri Kanunu ve Adalet Komisyonu Raporu, 1/574/393 (www. tbmm.gov.tr-Erişim tarihi: 09.05.2018).

[90] YHGK., 07.06.2017, E. 2017 / 1093, K. 2017 / 1090; “Az yukarıda değinildiği üzere ıslahın konusunu tarafların yaptıkları usul işlemleri oluşturduğundan taraflardan birinin ıslah yoluna başvurabilmesi için daha önce yapmış olduğu bir usul işleminin bulunması gerekir. Gerek mülga 1086 sayılı HUMK’ nın 83. maddesinde gerekse yargılama sırasında yürürlüğe giren 6100 sayılı HMK`nın 176. maddesinde taraflardan her birinin yapmış olduğu usul işlemlerini kısmen veya tamamen sslah edebileceği açık bir şekilde ifade edilmiştir. Bu nedenle cevap dilekçesinin ıslahı için öncelikle yapılması gereken usul işlemi davaya cevap vermekten ibarettir. Cevap dilekçesinin hiç verilmemiş olması halinde ortada ıslah edilmesi mümkün bir usul işleminin varlığından söz edilemez. Aksi halde, suskun kalınarak hiç cevap verilmemiş olması halinin bir usul işlemi olarak kabulü gerekir. Bu çerçevede süresi geçtikten sonra yapılan ve karşı çıkılan savunmanın da hiç yapılmamış gibi olduğunu ve aynı hukuki sonucu doğuracağını belirtmek gerekir. Usul işleminin ıslahla 
birinin yapmış olduğu usul işlemlerini ıslah edebileceği, cevap dilekçesinin ıslah edilebilmesi için öncelikle yapılması gereken usul işleminin davaya cevap vermekten ibaret olduğunu ve bu durumda ortada yapılmış bir usul işlemi olmadığı için cevap dilekçesi vermeyen davalının ıslah ile zamanaşımı def'ini ileri süremeyeceğini gerekçe göstermiştir. Doktrin ve uygulamada yaşanan bu görüş ayrılıklarının, içtihatların birleştirilmesi yolu ile giderilmesi gerektiği kanaatindeyim.

\section{C- Cevap Dilekçesi Verilmemesinin Yargılamaya Etkisi}

Davalının, aleyhinde açılmış olan davada cevap dilekçesi vermemesinin yapılacak yargılamaya da bir kısım etkileri vardır. Yargılamayı yapan mahkeme, kendiliğinden araştırma ilkesinin olduğu davalar hariç olmak üzere, davacının ileri sürdüğü vakıa ve delillerle bağlıdır. Çünkü davacının açmış olduğu davada davalı, davacının ileri sürdüğü vakıalara karşı ne yeni bir vakıa sunmuş ne de davacının sunduğu vakıalara, karşı iddiada bulunmuştur. Sonuç olarak davalı, sunulan vakıaları inkâr etmiş sayılmakta ve sadece inkâr kapsamında beyanda bulunabilmektedir. Mahkeme de zorunlu olarak sadece davacıya bu vakıaları ispat etmesi yönünde haklar tanıyacaktır.

Yargılamayı yapan mahkeme, sadece davacı tarafın sunmuş olduğu delilleri inceleyecek, eğer bu delillerin başka yerden getirilmesi gerekiyorsa ilgili yerlerden getirtecektir. Davalı, süresi içerisinde cevap dilekçesi sunmadığı için HMK m. 145 hükmü saklı kalmak kaydıyla, delil sunamayacaktır. Bu durumda mahkeme, davacının ileri sürdüğü vakıalar ve bunları ispata yarayan delillerle yargılamayı yapacak ve davacının haklı olduğuna kanaat getirirse davacı lehine karar verecektir. Bu nedenle yargılama, adeta sadece davacının iddia ve delilleri üzerine kurulacak ve davalı açısından olumsuz bir durum meydana gelecektir. Davalının inkâr kapsamında mahkemeye sunacağı beyanlar ise cevap dilekçesi vermediği için sadece davacının iddia ve delillerine karşı olacak ve davanın davacının iddia ve delilleri üzerine kurulması sonucunu değiştirmeyecektir.

düzeltilmesi öncelikle geçerli bir hukuki işlemin varlığını gerektirdiğinden, yapılmamış hükmünde sayılan bir usul işleminin sslahla düzeltilmesi de düşünülemez." (www.kazanci. com.tr-Erişim tarihi:09.05.2018). 


\section{SONUÇ}

Anayasa m. 36 hükmü gereğince herkes, yargı mercileri önünde meşru vasıta ve yollardan faydalanmak suretiyle davacı ve davalı olarak adil yargılanma hakkına sahiptir. Hukuk yargılamasında davalının aleyhinde açılan davaya karşı cevap verebilmesi, gösterilen tüm delillerden haberdar olması ve görüş bildirebilmesi gerek Avrupa İnsan Hakları Sözleşmesi' nde gerek Anayasa' da gerekse de kanunlarda adil yargılanma hakkı kapsamında gözetilmesi gereken bir ilke olarak belirtilmiştir. Davalı, kendisine tanınan bu hakkı kullanıp kullanmamakta serbesttir. Ancak bu hakkın kullanımı sınırsız değildir. Kanun koyucu, cevap dilekçesinin şekli açısından bir sınır çizmemişse de cevap dilekçesinde hangi unsurların bulunması gerektiğini, cevap dilekçesi verme süresini düzenlemiştir. Davalı, cevap dilekçesi ile usule ve maddi hukuka ilişkin savunma sebepleri ileri sürülebilmektedir. Davalı, dava dilekçesinin kendisine tebliğini müteakip iki haftalık süre içerisinde cevap dilekçesi hazırlayamayacağını düşünüyorsa mahkemeden ek süre talep edebilmektedir. Davalı eğer bir mazereti sebebiyle süresinde cevap dilekçesi verememişse, HMK m. 95-101' e istinaden eski hale getirme talebiyle bu hakkını kullanabilir.

Davalı süresi içerisinde cevap dilekçesi vermek sureti ile usule ve maddi hukuka ilişkin savunma sebeplerini ileri sürebileceği gibi, kasten veya ihmali olarak süresi içerisinde cevap dilekçesi vermemiş de olabilir. Davalının cevap dilekçesi vermemesi bazı sonuçlara bağlanmıştır. Bu kapsamda görülmekte olan dava, davacı tarafından dava açarken sunmuş olduğu vakıalar ve deliller esas alınarak görülüp sonuçlanacak, davacı yargılamada güçlü konuma gelecektir. Yargılamayı yapan mahkeme de davacının ileri sürdüğü vakıa ve delillerle bağlı olacak, sadece davacıya bu vakıaları ispat etmesi yönünde haklar tanıyacaktır.

HMK m. 128 hükmü gereğince, süresi içerisinde cevap dilekçesi vermemiş olan davalı, davacının dava dilekçesinde ileri sürdüğü vakıaların tamamını inkâr etmiş sayılacaktır. Bu düzenleme, davalının susmasının inkâr olarak kabul edildiğini göstermektedir. Davalı, cevap dilekçesi vermediği için yeni vakıa ve delil ileri süremeyecektir. Ancak gerek ön inceleme aşamasında gerekse de tahkikat aşamasında inkâr kapsamında beyanda bulunabilecektir. Bu beyan dilekçesinde davaya yönelik yeni vakıa ileri süremeyecek, itiraz ve def' ilerini de bildirilemeyecektir.

Kasıtll veya ihmali olarak cevap dilekçesi verme süresini geçirmiş olan davalıya, adil yargılanma ve hukuki dinlenilme hakkı kapsamında, hakkaniyet gereği ıslah hakkının tanınması gerekmektedir. Bu nedenle, sslah yoluyla yahut karşı tarafın açık muvafakati ile tahkikat aşamasında davalı cevap dilekçesi verebilecektir. Aksinin kabulü halinde yapılan yargılamada davalıya temel haklarının 
tanındığını söylemek mümkün olmayacaktır. Cevap dilekçesi verilmesinin bazı koşullara bağlanmış olmasının sebebi, yargılamanın makul bir sürede bitirilmesi ve davanın sürüncemede kalmaması içindir. Davalı, cevap dilekçesi ile iddialarını ve delillerini sunabilmesi için makul bir fırsata sahiptir. Davacıya karşı kendisini dezavantajlı konuma sokmamak açısından süresi içerisinde cevap dilekçesini sunması ve savunma hakkını kullanması gerekmektedir. Aksi takdirde sonuçlarına da katlanmak yükümü altındadır. 


\section{KAYNAKÇA}

Alangoya, Yavuz: Medeni Usul Hukukunda Vakıaların ve Delillerin Toplanmasına İlişkin İlkeler, İstanbul 1979.

Alangoya, H. Yavuz / Yıldırım, M. Kamil / Eren-Yıldırım, Nevhis: Medeni Usul Hukuku Esasları, Genişletilmiş Gözden Geçirilmiş 7. Baskı, İstanbul 2009.

Ansay, Sabri Şakir: Islah, AÜHFD 1950, C:7, S:1-2, (s.122-129).

Ansay, Sabri Şakir: Hukuk Yargılama Usulleri, Ankara 1960.

Aras, Aslı: Cevap Dilekçesi Verilmesinin Hukuki Sonuçları, D.E.Ü. Hukuk Fakültesi, Prof.Dr. Şeref Ertaş’a Armağan, C:19, Özel Sayı, (s.1927-1952).

Arslan, Ramazan / Yılmaz, Ejder / Taşpınar-Ayvaz, Sema: Medeni Usul Hukuku, 1. Bask1, Ankara 2016.

Ateş, Mustafa: Hukuk Muhakemeleri Kanunu, Yargıtay İlke Kararları, C:1-2, 1. Bask1, Ankara 2013.

Baumbach, Adolf/Lauterbach, Wolfgang/Albers, Jan/Hartmann, Peter: Zivilprozessordnung, München 2014.

Berkin, Necmettin M.: Medeni Usul Hukuku Esasları, İstanbul: Hamle Matbaası 1969.

Bilge, Necip: Medeni Yargılama Hukuku, 2. Baskı, Ankara 1967.

Bolayır, Nur: Hukuk Yargılamasında Delillerin Toplanmasında Tarafların ve Hâkimin Rolü, 1. Baskı, İstanbul 2014.

Bozkurt, Argun: İş Yargılaması Usul Hukuku, Ankara 1999.

Budak, Ali Cem: Medeni Usul Hukuku, İstanbul 2017.

Budak, Ali Cem/Karaaslan, Varol: Medeni Usul Hukuku, 1. Baskı, Ankara 2017.

Çelikoğlu, Cengiz Topel: Hukuk Muhakemeleri Kanununa Göre Dava ve Cevap Dilekçeleri, Terazi Hukuk Dergisi, S:63, Y:6, Kasım 2011, (s.48-60).

Erdönmez, Güray: Hukuk Muhakemeleri Kanunu Bakımından Delillerin İbrazı, Medeni Usul ve İcra İflas Hukukçuları Toplantısı X, 1-2 Ekim 2012 İzmir, (s.348-376).

Erdönmez, Güray: Hukuk Muhakemeleri Kanununa Göre Delillerin Gösterilmesi ve İbrazı, İstanbul Barosu Dergisi, Eylül-Ekim 2013, C: LXXXVII, S:5, (s. 15-53). 
Ermenek, İbrahim: Medeni Usul Hukukunda Davayı Kabul, Ankara 2009. Eroğlu, Orhan: Islah, 1. Baskı, Ankara 2017.

Fleming, James Jr. / Geoffrey, C. Hazard Jr. / Leubsdorf, John: Civil Procedure, Newyork 2001.

Friedenthal, Jack H./Kane, Mary Kay/Miller, Arthur R.: Civil Procedure, St.Paul 2015.

Gençsan, Ömer Uğur: 6100 Sayılı Hukuk Muhakemeleri Kanunu Yorumu, 1. Baskı, Ankara 2013.

Görgün, L. Şanal: Medeni Usul Hukuku, 4. Baskı, Ankara 2015.

Görgün, L. Şanal / Börü, Levent / Toraman, Barış / Kodakoğlu, Mehmet: Medeni Usul Hukuku 6. Baskı, Ankara 2017.

Gündüz, Okan: Anglo-Amerikan Hukuku Işığında Medeni Yargılama Hukukunda Dava Yöntemi, Ankara 2009.

İnal, Nihat: Açıklamalı Hukuk Yargılama Usulü Yasası, C:1, Ankara 2003.

Jauernig, Othmar / Hess, Burkhard: Zivilprozessrecht, München 2011.

Karafakih, İsmail Hakkı: Hukuk Muhakemeleri Usulü Esasları, Ankara 1952.

Karafakih, İsmail Hakkı: Cevap Layihası Vermemiş olan Davalı Müruruzaman Dermeyan Hakkını İskat Etmiş Midir?, İstanbul Barosu Dergisi, 1962/1,2,3, (s. 13-19).

Karahacıoğlu, Ali Haydar / Parlar, Aynur: Davanın Açılması ve Aşamaları, 1. Baskı, Ankara 2012.

Karslı, Abdurrahim: Medeni Usul Hukukunda Usuli İşlemler, İstanbul 2001.

Karslı, Abdurrahim: Medeni Muhakeme Hukuku, 4. Baskı, İstanbul 2014.

Karslı, Abdurrahim/Koç, Evren/Konuralp, Cengiz Serhat: Hukuk Muhakemeleri Kanunu’nda Problemli Konular, 1. Baskı, İstanbul 2014.

Kaya, Cemil/Akcan, Recep: Medeni ve İdari Yargıda İddia ve Savunmanın Genişletilmesi veya Değiştirilmesi Yasağı, İ̈HHFM, C:LXVII, S. 1-2, (s.123-142), İstanbul 2009.

Kılıçoğlu, Mustafa: 6100 Sayılı Hukuk Muhakemeleri Kanunu El Şerhi, 1. Baskı, İstanbul 2012.

Kiraz, Taylan Özgür: Medeni Yargılama Hukukunda İkrar, Ankara 2005. 
Kuru, Baki: Hukuk Muhakemeleri Usulü El Kitabı, 1. Baskı, İstanbul 1995.

Kuru, Baki: Hukuk Muhakemeleri Usulü, C: I,II,III,IV, 6. Baskı, İstanbul 2001, (Kuru,Şerh).

Kuru, Baki: Medeni Usul Hukuku, İstanbul 2015, (Kuru, Usul).

Kuru, Baki: Medeni Usul Hukuku Ders Kitabı, Ankara 2015, (Kuru, Ders Kitabi).

Kuru, Baki: İstinaf Sistemine Göre Yazılmış Medeni Usul Hukuku, 1. Baskı, Ankara 2016, (Kuru, İstinaf).

Kuru, Baki / Arslan, Ramazan / Yılmaz, Ejder: Medeni Usul Hukuku Ders Kitab1, 25. Baskı, Ankara 2014.

Loughlin, Paula / Gerlis, Stephen: Civil Procedure, Londra 2004.

Meriç, Nedim: Zamanaşımı Def' ine İlişkin Bazı Medeni Yargılama Hukuku Meseleleri (Haluk Konuralp Anısına Armağan, C.1, 1. Baskı, Ankara 2009, (s.679-704).

Muşul, Timuçin: Medeni Usul Hukuku, 3. Baskı, Ankara 2012.

Neil, Andrews: English Civil Procedure, Norfolk 2003.

Okur, Mustafa: Medeni Usul Hukukunda Davaya Cevap, Yayınlanmamış Y.Lisans Tezi, Ankara 2002.

Olgun, Sevinç: Islah Yolu İle Düzeltilemeyecek İşlemler, Terazi Hukuk Dergisi, S:16, Y:2, Ankara Aralık 2007, (s.43-53).

Öner, Erdoğan/Değirmenci, Cenker: Damga Vergisi ve Harçlar Bilgisi, Ankara 2017.

Özekes, Muhammet: Medeni Usul Hukukunda Hukuki Dinlenilme Hakkı, Ankara 2003.

Pekcanıtez, Hakan: Hukuki Dinlenilme Hakkı, Prof.Dr. Seyfullah Edis'e Armağan, İzmir 2000, (s.753-791).

Pekcanıtez, Hakan/Akyazılı, Erdem: Islaha İlişkin Bazı Yargıtay Kararlarının İncelenmesi, Uğur Alacakaptan’a Armağan, İstanbul 2008, (s.553-559).

Pekcanıtez, Hakan / Atalay, Oğuz / Özekes, Muhammet: Medeni Usul Hukuku, 14. Baskı, Ankara 2013.

Pekcanıtez, Hakan / Özekes, Muhammet / Akkan, Mine / Taş-Korkmaz, Hülya: Medeni Usul Hukuku, C:II, 15. Baskı, İstanbul 2017. 
Pohlman, Petra: Zivilprozessrecht, Mühchen 2011.

Postacıoğlu, İlhan: Medeni Usul Hukuku Dersleri, İstanbul 1966.

Postacıŏlu, İlhan: Davanın ve Kaziyei Muhkemenin Unsuru Olarak Hukuki Sebep, Dr. A. Recai Seçkin'e Armağan, Ankara 1974, (s.497-527), ( Postacıoğlu, Hukuki Sebep).

Postacıoğlu, İlhan / Altay, Sümer: Medeni Usul Hukuku Dersleri, 7. Baskı, İstanbul 2015.

Rosenberg / Schwab / Gottwald: Zivilprozessrecht, 15., Auflage 1983.

Selçuk, Ruza Nurettin: Davaya Cevap, Ankara Barosu Dergisi, 1989/5 (s.840-849).

Sime, Stuart: Civil Procedure, Newyork 2004.

Sungurtekin-Özkan, Meral: Türk Medeni Yargılama Hukuku, 1. Baskı, İzmir 2013.

Tanriver, Süha: Mahkeme Huzurunda Yapilan Kabuller, AÜHFD 1995/IIV, (Tanriver, Kabul).

Tanrıver, Süha: İlamlı İcra Takibinin Dayanakları ve İcranın İadesi, Ankara 1996, (Tanrıver, İlamlı).

Tanrıver, Süha: Medeni Usul Hukuku, C:I, 1. Baskı, Ankara 2016.

Topuz, Gökçen/Topuz, Seçkin: Takasın Davada ileri Sürülmesi, AÜHFD, Y1l: 2008, C:57, S: 3.

Tutumlu, Mehmet Akif: Medeni Yargılama Hukukunda Delillerin İleri Sürülmesi, 4. Baskı, Ankara 2007.

Tutumlu, Mehmet Akif: Cevap Dilekçesinde Gösterilmeyen Delile (Tanık) Tahkikat Aşamasında Dayanılabilir mi? Terazi Aylık Hukuk Dergisi, C:9, S:95, Temmuz 2014, (s.116-118).

Tutumlu, Mehmet Akif: Medeni Usul Hukukunda Islah, 3. Baskı, Ankara 2015.

Tutumlu, Mehmet Akif: Cevap Dilekçesi Vermeyen Davalının Delil Gösterme Hakkı Düşer mi?, Terazi Aylık Hukuk Dergisi, C:11, S:120, Ağustos 2016, (s.134-138).

Tutumlu, Mehmet Akif: Ek Cevap Süresinin Verilme Koşulları, Başlangıç Tarihi ve Hesaplanması, Terazi Hukuk Dergisi, C:11, S:123, Kasım 2016, (s.106-108). 
Ulukapı, Ömer: Medeni Usul Hukuku, 3. Baskı, Konya 2015.

Umar, Bilge: Hukuk Muhakemeleri Kanunu Şerhi, 2. Baskı, Ankara 2014.

Üstündağ, Saim: Borçlar Hukuku Hükümlerine Göre Takas ve Davada Kullanılmasının Arz Ettiği Özellikler, İstanbul Üniversitesi Hukuk Fakültesi Mecmuası 1959, C.XXV, S:1-4.

Üstündăg, Saim: Süresinde Cevap Lahiyası Vermemenin Müeyyidesi Vardır, İstanbul Barosu Dergisi, 1966/4,5,6, (s.22-36).

Üstündağ, Saim: İddia ve Müdafaanın Değiştirilmesi Yasağı, İÜHFY. No:266, İstanbul 1967

Üstündă̆, Saim: Medeni Yargılama Hukuku, C:1,2, 7. Baskı, İstanbul 2000.

Yavuz, Nihat: Hukuk Davalarında, Davalının Savunma Vasıtaları, Adalet Dergisi, Y:66, S:5-6, (s.638-650).

Yıldırım, M. Kamil: Medeni Usul Hukukunda Delillerin Değerlendirilmesi, İstanbul 1990.

Yıldırım, M. Kamil: İlkeler Işı̆̆ı Altında Medeni Yargılama Hukuku, İstanbul 2011.

Yılmaz, Ejder: Dünden Bugüne Hukuk Usulü Muhakemeleri Kanunumuz (Cumhuriyetin Kuruluşundan Bugüne Türk Hukukunun Seksen Yıllık Gelişimi, Sempozyum, Ankara, 2003, (YILMAZ, Sempozyum), (s. 243-278).

Yılmaz, Ejder: Davada Takas ve Mahsup Talebi, MİHDER, 2010/2.

Yilmaz, Ejder: Hukuk Muhakemeleri Kanununun Getirdikleri, Ankara Barosu Dergisi 2011/2,(s.236-253).

Yılmaz, Ejder: Hukuk Muhakemeleri Şerhi, 1. Baskı, Ankara 2012.

Yılmaz, Ejder: Medeni Yargilama Hukukunda Islah, 6100 sayılı HMK'na göre Değiştirilmiş, 4. Baskı, Ankara 2013.

Yılmaz, Ejder: Hukuk Muhakemeleri Kanunu Şerhi, Ankara 2016.

Yilmaz, Orhan: Esasa Verilebilecek Cevaplar, TBBD, 1990/3, (s.401-414).

Yılmaz, Ramazan: HMK Uyarınca Tüm Delillerin Dava veya Cevap Dilekçesinde Gösterilmesi ve Eklenmesinin Zorunlu Olup Olmadığı, İstanbul Barosu Dergisi, C:86, S:2012/5, (s.262-265).

Zeiss, Walter: Zivilprozessrecht, 9., Auflage 1997. 
Zekeriya Yılmaz: Hukuk Muhakemeleri Kanunu ve Getirdiği Yeni Hükümler, Ankara 2012. 